\title{
Teaching with Emotion: Enriching the Educational Experience of First-Year Law Students
}

\author{
GRANT H. MORRIS*
}

\section{TABLE OF CONTENTS}

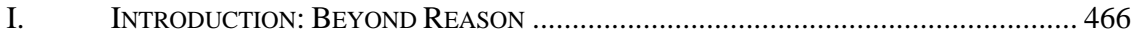

II. EXPERIENCING EMOTION: EXAMPLES FROM A TORTS CLASS …….........................4 476

A. The First Question ................................................................................. 476

B. Intentional Infliction of Emotional Distress .......................................... 479

C. Negligence: The Applicable Standard of Care .............................................. 484

1. The Reasonable Person Standard:

Gender Neutral or Gender Specific? ................................................ 484

2. The Reasonable Person Standard Contrasted with the Economic Person Standard........................................................ 487

3. The Standard of Care for Physicians ................................................... 490

D. Negligence: Limitations on Duty To Act ................................................ 493

1. The Failure To Rescue ................................................................... 494

2. The Failure To Rescue: Revisited ......................................................... 497

3. Attorney Duty of Confidentiality ..................................................... 500

4. Negligently Inflicted Emotional Distress:

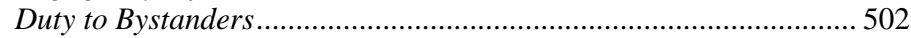

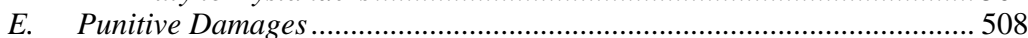

F. $\quad$ Products Liability: Defining Defect .................................................. 512

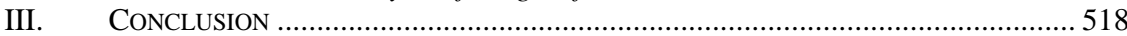

* (C) 2010 Grant H. Morris. Professor of Law, University of San Diego School of Law; Clinical Professor, Department of Psychiatry, School of Medicine, University of California, San Diego. I wish to express my sincere appreciation to the University of San Diego for the financial support it provided for this project. 


\title{
I. INTRODUCTION: BEYOND REASON
}

\author{
since feeling is first \\ who pays any attention \\ to the syntax of things \\ will never wholly kiss you; \\ ... \\ and kisses are a better fate \\ than wisdom. ${ }^{1}$
}

Christopher Columbus Langdell paid attention to the syntax of things. Law, he insisted, was a science whose principles or doctrines can be mastered only by studying appellate court cases. ${ }^{2}$ To subject law's decisionmaking process to scientific inquiry, ${ }^{3}$ Langdell introduced the case method, focusing the attention of law students on the specific issues presented in appellate court cases and the intellectual analysis of the judges leading to the resolution of those issues. ${ }^{4}$ Law professors using the case method do not lecture; rather, they employ Socratic dialogue to probe their students' analysis of the issues in the cases being studied.

1. e.e. cummings, since feeling is first, in IS 5 (1926), reprinted in E.E. CuMMINGS, COMPLETE PoEms 1904-1962, at 291 (George J. Firmage ed., 1994). Consider also these lyrics from a song by Bob Dylan: "I stood unwound beneath the skies/And clouds unbound by laws.” BoB Dylan, Lay Down Your Weary Tune, on BiOgRAPH (Colombia Records 1985).

2. In the preface to his contracts casebook, Langdell wrote:

Law, considered as a science, consists of certain principles or doctrines. To have such a mastery of these as to be able to apply them with constant facility and certainty to the ever-tangled skein of human affairs, is what constitutes a true lawyer; and hence to acquire that mastery should be the business of every earnest student of law. ... [T] [he shortest and best, if not the only way of mastering the doctrine effectually is by studying the cases in which it is embodied.

C.C. LANGDELL, A SELECTION OF CASES ON THE LAW OF CONTRACTS, at vi (1871).

3. Anthony Kronman suggested that Langdell's conception of law as a science was inspired by a geometrical model of the scientific method. ANTHONY T. KRONMAN, THE LOST LAWYER: FAILING IDEALS OF THE LEGAL PROFESSION 171 (1993).

4. To Langdell, legal education was a science to be taught at a university, not a craft to be learned at a lawyer's side. Through use of the case method, Langdell was able to shift the training of lawyers from law offices as apprentices to the university classroom as students. See John J. Costonis, The MacCrate Report: Of Loaves, Fishes, and the Future of American Legal Education, 43 J. LegAL EDUC. 157, 160 (1993). The elementary principles of contracts, torts, or other areas of law are discovered by surveying the case law in that subject. "Once they have been identified, it is then the task of scholars to work out, in an analytically rigorous manner, the subordinate principles entailed by them.” Kronman, supra note 3, at 171. 
Through a rigorous analysis of those issues, law students are educated to "think like lawyers."

The case method with Socratic dialogue continues today as the "signature pedagogy" of legal education. ${ }^{6}$ However, in its singular quest to sharpen the ability of law students to engage in analytic reasoning, this method trivializes and even suppresses students' values and emotions and the role they play in conflict resolution. ${ }^{7}$ Such matters are not considered

5. Although the terms "to think like a lawyer" or "to think like lawyers" are commonly used, correct English grammar calls for the substitution of "as" for "like.” A well-educated law student thinks as a lawyer thinks.

6. William M. Sullivan et Al., The Carnegie Found. FOR the AdvanCEMEnt

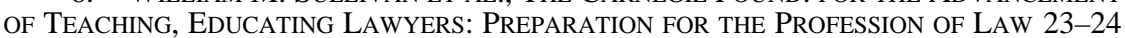
(2007). "[T]he deep structure of the pedagogy is that 'thinking like a lawyer' is about processes of analytic reasoning and the grasp of legal 'doctrine' and principles rather than learning a system of statutory or 'black letter' law.” Id. at 24. A survey of law schools revealed that the Socratic dialogue is the predominant teaching methodology used in law school classes. Socratic dialogue is used in $97 \%$ of first-year courses, 93\% of upperclass courses, and even 67\% of seminars. Steven I. Friedland, How We Teach: A Survey of Teaching Techniques in American Law Schools, 20 SEATTLE U. L. REV. 1, 27 (1996).

7. See, e.g., Lila A. Coleburn \& Julia C. Spring, Socrates Unbound: Developmental Perspectives on the Law School Experience, 24 LAW \& PSYCHOL. REV. 5, 26 (2000) (asserting that law professors teach "students how to substitute reason and rigorous analysis for emotion and lay ways of looking at things"). "The only passion valued in this classroom is that for reason and the right answer." Id.; Angela P. Harris \& Marjorie M. Shultz, “A(nother) Critique of Pure Reason”: Toward Civic Virtue in Legal Education, 45 STAN. L. REV. 1773, 1773 (1993) ("[T]he phrase 'thinking like a lawyer' means suppressing or denying one's feelings and personal experience while putting forth a 'cold' analysis of the 'facts.'”); Gerald F. Hess, Heads and Hearts: The Teaching and Learning Environment in Law School, 52 J. LEGAL EDUC. 75, 78-79 (2002) (asserting that conventional legal education "teaches that tough-minded analysis, hard facts, and cold logic are the tools of a good lawyer, and it has little room for emotion, imagination, and morality"); Terry A. Maroney, Law and Emotion: A Proposed Taxonomy of an Emerging Field, 30 LAW \& HuM. BEHAV. 119, 120 (2006) (“A core presumption underlying modern legality is that reason and emotion are different beasts entirely: they belong to separate spheres of human existence; the sphere of law admits only of reason; and vigilant policing is required to keep emotion from creeping in where it does not belong."); Michael Meltsner, Feeling Like a Lawyer, 33 J. LEGAL EDUC. 624, 628 (1983) ("Many lawyers and law teachers are committed to getting the job done, to performing, to dealing with behavior divorced from feelings about that behavior, to narrowly conceiving legal problems, to not playing head shrinker, to avoiding what might be labeled 'touchyfeely,' to objectifying and to not subjectifying legal work.”); Marjorie A. Silver, Emotional Intelligence and Legal Education, 5 PsYCHOL. PUB. POL'Y \& L. 1173, 1181 (1999) (asserting that "the emphasis on rational, analytical discourse and the Socratic method in law school .... contribute[s] to the devaluation and denial of emotional processes and influences”); Andrew S. Watson, The Quest for Professional Competence: Psychological Aspects of Legal Education, 37 U. CIN. L. REV. 91, 124 (1968) ("[T]he Socratic Method exaggerates, and in a sense, distorts the importance of intellect. . . . [W]hen the Socratic 
worthy of class discussion. Students are taught "to think like lawyers," but they are not taught to "feel like lawyers." asserted that in order to ensure that students develop "a 'tough-minded' and analytical attitude toward lawyer tasks and professional roles," the ordinary religion of the law school classroom requires the law professor to "stress cognitive rationality along with 'hard' facts and 'cold' logic and 'concrete' realities. Emotion, imagination, sentiments of affection and trust, a sense of wonder or awe at the inexplicable - these soft and mushy domains of the 'tender minded' are off limits for law students." Professor Kingsfield informed his class, "You come in here with a skull full of mush, and you leave thinking like a lawyer."10 Students are denied the opportunity to develop as well-rounded human beings with high ethical values and with the interpersonal skills necessary to understand $^{11}$ and respond appropriately to their clients' concerns. ${ }^{12}$ When values and emotional issues are ignored, students are depersonalized ${ }^{13}$ and their level of distress rises. ${ }^{14}$

Method leads to an ablation of emotional awareness, it can have a seriously distorting effect. ... The Socratic Method reinforces the false image that it is possible to get rid of emotion, and the nature of the Socratic arena in some law schools makes it sound possible to achieve this impossible goal.”).

8. I do not agree with those who assert that teaching students to feel like lawyers means teaching that it is right to be controlling, cool, dispassionate, unfeeling, and arrogant. See Meltsner, supra note 7, at 624 (attributing the assertion to David Kaplow). Rather, feeling like lawyers requires that they consider the emotional and social consequences of decisions. Susan Daicoff, Lawyer, Know Thyself: A Review of Empirical Research on Attorney Attributes Bearing on Professionalism, 46 AM. U. L. REV. 1337, 1381 (1997).

9. Roger C. Cramton, The Ordinary Religion of the Law School Classroom, $29 \mathrm{~J}$. Legal Educ. 247, 250 (1978). The 2007 Carnegie Report proclaimed: "In their allconsuming first year, students are told to set aside their desire for justice. They are warned not to let their moral concerns or compassion for the people in the cases they discuss cloud their legal analyses.” SulLIVAN ET AL., supra note 6, at 187.

10. A statement spoken by John Houseman, an actor, portraying Professor Charles W. Kingsfield, Jr., in the motion picture adaptation of JOHN JAY OsBORN, JR., THE PAPER CHASE (Whitston Publ'g Co. 2003) (1971).

11. For example, in discussing the Equal Protection Clause, should students consider the perspective of an African American person on a segregated bus in the South in the 1950s? He or she was permitted to ride on the bus and to arrive at his or her destination at the same time as a white person, and the fare for both passengers was equal. But is the African American person denied equal protection if he or she was compelled to ride only in the back of the bus? Ask Rosa Parks for her opinion. For an explanation as to why the Author chooses not to hyphenate African American(s), see Grant H. Morris, Greatest Legal Movie of All Time: Proclaiming the Real Winner 47 SAN DiEGo L. REV. 735, 739 n.21 (2010).

12. See Watson, supra note 7 , at 117 .

13. See Hess, supra note 7 , at 79 ("For some students, 'learning to think like a lawyer' means abandoning their ideals, ethical values, and sense of self."); Lawrence S. Krieger, Institutional Denial About the Dark Side of Law School, and Fresh Empirical Guidance for Constructively Breaking the Silence, 52 J. LEGAL EDUC. 112, 117 (2002) 
But emotion will not be stifled. Susan Bandes began her landmark book on the relationship of emotion to law by declaring: "Emotion pervades the law." 15 Indeed, as Laura Little aptly asserted: "Emotions are so key to the richness of life that no effort to understand humans and human society could make any claim to accuracy or completeness without taking them into account."16 Even though there is no unequivocal agreement on how "emotion" should be defined or its exact relationship to cognition, ${ }^{17}$ insights from psychology, philosophy, anthropology, and neurobiology indicate that emotion acts in concert with cognition to shape perceptions and reactions. ${ }^{18}$ More than forty years ago, psychiatrist Andrew Watson proclaimed: "Emotions are part and parcel of the biological reactivity of the human animal and are therefore irremovable. While they may be modified and grotesquely distorted, they are always present to influence all human behavior ...."19 Lila Coleburn, a clinical psychologist, and her co-author, Julia Spring, the Director of Student Counseling at Columbia Law School, wrote:

Because of the very complexity of human perception, emotion is needed to assist in sorting through information and exercising judgment about life situations, legal and other. Reason and emotion are melded in human cognition; our reasoning strategies are bound up with our feelings, for better or worse. Although feelings can impair the quality of reasoning, their lack is also an

(“Thinking 'like a lawyer' is fundamentally negative; it is critical, pessimistic, and depersonalizing.”).

14. G. Andrew H. Benjamin et al., The Role of Legal Education in Producing Psychological Distress Among Law Students and Lawyers, 1986 AM. B. FounD. Res. J. 225, 225.

15. Susan A. Bandes, Introduction to The Passions of LAw 1, 1 (Susan A. Bandes ed., 1999).

16. Laura E. Little, Negotiating the Tangle of Law and Emotion, 86 CoRnELL L. REV. 974, 975 (2001) (reviewing THE PASSIONS OF LAW, supra note 15).

17. Id. at 981. For an in-depth discussion of the debates about the taxonomy and definition of emotion, see id. at 981-86; for an in-depth discussion of the debates about the relationship between cognition and emotion, see id. at 987-92. Susan Bandes acknowledged: "Emotion theorists have never come close to agreeing on a definition of emotion; indeed, there seems to be widespread agreement on the impossibility of finding one.” Bandes supra note 15, at 10. Nevertheless, Professor Bandes asserted that a discussion of emotion's relationship to law "can proceed despite the lack of definition." Id.

18. Bandes, supra note 15 , at 7.

19. Watson, supra note 7 , at 124. 
impairment, and nothing resembling so-called pure reason is met in human life except in cases of serious pathology. ${ }^{20}$

Over the last half century, an extensive "law and emotion" literature has emerged. ${ }^{21}$ Early researchers focused on the deleterious effects of legal education on law students - especially on first-year law students. In 1986, a large empirical study published in the American Bar Foundation Research Journal reported that $17 \%-40 \%$ of the 320 students and alumni studied "suffered significant levels of depression" 22 and that $20 \%-40 \%$ "reported other significantly elevated symptoms, including obsessive-compulsive, interpersonal sensitivity, anxiety, hostility, paranoid ideation, and psychoticism (social alienation and isolation)."23 Andrew Benjamin and his colleagues found that before entering law school, these individuals tested within the normal range for such symptoms, but that within a few months after law school began, first-year law students were experiencing severe psychological disturbances - they scored two standard deviations above normal expectation. ${ }^{24}$

Legal educators did not respond to this proof of their students' distress. In a longitudinal study of law students published in the Journal of Legal Education in 2002, Kennon Sheldon and Lawrence Krieger confirmed

20. Coleburn \& Spring, supra note 7, at 23 (footnote omitted). See also James B. Levy, As a Last Resort, Ask the Students: What They Say Makes Someone an Effective Law Teacher, 58 ME. L. REV. 49, 57 (2006) ("[E]motion is such an integral part of our brain's cognitive functioning that we literally would be unable to learn or solve problems if not for its role in assigning meaning and a context to every experience.”); Meltsner, supra note 7, at 633 ("While only an extreme anti-intellectual would disregard the importance of objective thought, rational deduction, and empirical proof to the practice of law, a method of training lawyers which ignores the intuitive, the emotive, and the personal belongs not to the history of science but to the history of pseudoscience.”).

21. In an article that attempts to classify "law and emotion" scholarship, the author lists 205 references, consisting of 195 books, articles, and symposia, plus 10 court cases, on law and emotion topics that were published between 1930 and 2006. Only 30 of those 205 references, consisting of 26 books, articles, and symposia and 4 court cases, were published prior to 1980. Maroney, supra note 7, at 136-42.

22. Benjamin et al., supra note 14, at 236.

23. Id.

24. Id. at 240. After only six months of law school, many students were reported to be suffering extreme stress. They were concerned about their ability to meet the perceived high standards of law school, and they experienced feelings of inadequacy and inferiority. Id. at 244. First-year students were overwhelmed. Id. at 247. See also Matthew M. Dammeyer \& Narina Nunez, Anxiety and Depression Among Law Students: Current Knowledge and Future Directions, 23 LAW \& Hum. BeHAV. 55, 63 (1999) (reporting that in that some studies, anxiety measured in law students "is comparable to psychiatric populations”). Law students also reported suffering depression at a higher rate than experienced by the general population and by comparison groups, such as medical students. Id. at 67 . 
the conclusions of the Benjamin study. ${ }^{25}$ Although students entered law school as normal, healthy human beings, "[w]ithin six months, [they] experienced marked decreases in well-being and life satisfaction and marked increases in depression, negative affect, and physical symptoms."26 In the sixteen years since the startling results of the Benjamin study were published, nothing had changed. ${ }^{27}$

The nearly exclusive use of the case method in the first year contributes significantly to student anxiety. The individual cases fail to provide students with a theoretical framework to serve as a needed context for their understanding of the area of law under consideration. ${ }^{28}$ Does the particular case under discussion stand for a generally accepted proposition, or for some possible future trend, or even as an exception to the general rule? Without such a framework, students - especially first-year studentsare confused.

Additionally, most first-year courses are taught to classes of 75 , or 100 , or more students by a professor who employs a Socratic dialogue. Thus, before a large group of colleagues, a student is forced to respond to a professor's interrogation. When each attempted answer elicits another question from the professor who never seems satisfied with any response, ${ }^{29}$ the student being questioned becomes anxious, ${ }^{30}$ embarrassed, ${ }^{31}$

25. Krieger, supra note 13, at 122. Although Lawrence Krieger is the sole author of this article, the research project was conducted by Kennon Sheldon and Lawrence Krieger. Id. For a more complete discussion of the research, see Kennon M. Sheldon \& Lawrence S. Krieger, Does Legal Education Have Undermining Effects on Law Students? Evaluating Changes in Motivation, Values, and Well-Being, 22 BEHAV. SCI. \& L. 261 (2004).

26. Krieger, supra note 13, at 122.

27. See Grant H. Morris, Preparing Law Students for Disappointing Exam Results: Lessons from Casey at the Bat, 45 SAN DiEgo L. REV. 441, 444 nn.16-18 (2008) (listing law review articles written by psychiatrists, law professors, and law students attesting to the stress and anxiety experienced by students in the process of receiving a legal education).

28. See Alan Watson, Legal Education Reform: Modest Suggestions, 51 J. LEGAL EDUC. 91, 93 (2001) (asserting that in the absence of such framework, cases cannot be fully understood and appreciated and are "largely incomprehensible" to students).

29. See, e.g., Watson, supra note 7, at 123 ("Since most professorial responses are questions, they are perceived as never-ending demands, and hoped-for relief never comes into sight.”).

30. See, e.g., id. at 121 (specifically mentioning anxiety as a student response to a law professor's use of Socratic dialogue).

31. Michael J. Patton, The Student, the Situation, and Performance During the First Year of Law School, 21 J. LEGAL EDUC. 10, 37 (1968) (specifically mentioning embarrassment as a student response to a law professor's use of Socratic dialogue). 
vulnerable, ${ }^{32}$ intimidated, ${ }^{33}$ even terrified. ${ }^{34}$ As Duncan Kennedy, then a law student at Yale, aptly asserted: "[T]here is a point at which no amount of intellectual interest will overcome your fear and revulsion at the spectacle of the professor smiling quietly to himself as he prepares to lay your guts out on the floor yet once again, paternally." 35 Even wellintentioned professors, employing a "kinder and gentler"36 Socratic version, may be perceived — or misperceived-by students as sadistic ${ }^{37}$ enemies, ${ }^{38}$ trying to destroy them.

32. Watson, supra note 7 , at 121 (specifically mentioning a "sense of helpless vulnerability" as a student response to a law professor's use of Socratic dialogue). See also Michael E. Carney, Narcissistic Concerns in the Educational Experience of Law Students, 18 J. PsychiatRY \& L. 9, 17 (1990) ("Through [the] emphasis on a rigorous questioning attitude, law school education can threaten the personal values by which many students define themselves as distinct and special.”).

33. Robert Stevens, Law Schools and Law Students, 59 VA. L. ReV. 551, 641 (1973) (specifically mentioning a feeling of intimidation as a student response to a law professor's use of Socratic dialogue). See Watson, supra note 28, at 91 ("Some teachers deliberately set out to intimidate students.”).

34. See Alan Watson, The Shame of American Legal Education 88 (2006) ("[F]irst-year law school is education by terror . . . ."); Watson, supra note 28, at 91 (reporting that students assert that first-year legal education is terrifying). Duncan Kennedy, writing as a law student, asserted that the terror experienced by first-year law students is "a particular kind of terror: that of a person who knows himself defenseless before a person who has a demonstrated desire to hurt him. ... The fear is the fear of the victim." Duncan Kennedy, Comment, How the Law School Fails: A Polemic, Yale REV. L. \& Soc. ACtion, Spring 1970, at 71, 75. See also Osborn, supra note 10, ("When Hart, seat 259, heard his name, he froze. Caught unprepared, he simply stopped functioning. Then he felt his heart beat faster than he could ever remember its beating and his palms and arms break out in sweat.”); SCOTT TURROw, ONE L 298 (1977) (describing legal education as "a schooling characterized by terror and the suppression of feeling").

35. Kennedy, supra note 34 , at 80.

36. The influx of significant numbers of women into the law student body has been credited with the "softening" of the Socratic dialogue in law classes. While men are considered to be rights-oriented thinkers, women are considered to be care-oriented thinkers. A rigid adherence to "hard" Socratic interrogation and a complete failure to consider the perspective of female law students could be considered discriminatory. See, e.g., Sandra Janoff, The Influence of Legal Education on Moral Reasoning, 76 MinN. L. REV. 193, 234-38 (1991). Susan Bandes credits feminist jurisprudence "for many of law's early forays into emotion theory." Susan Bandes, What's Love Got To Do with It?, 8 WM. \& MARY J. WOMEn \& L. 97, 98 (2001). Despite the "softening" of the Socratic dialogue in modern law school classes, the absence of periodic feedback on student classroom performance and the use of one final examination to measure student course performance remain today as major sources of student psychological stress. See, e.g., Morris, supra note 27, at 448-53. Barbara Glesner Fines notes that although "the days of ... professorial hazing ... are rapidly receding," nevertheless, "an educational philosophy grounded in a competitive ethos" remains. Barbara Glesner Fines, Fundamental Principles and Challenges of Humanizing Legal Education, 47 WASHBURN L.J. 313, 315, 316 (2008).

37. See Kennedy, supra note 34, at 74 (acknowledging that not all law professors are unrestrained sadists, but asserting "there must be something deeply corrupting about 
Because emotion plays a vital role in the learning process, one would assume that legal scholars would not only decry the impact of negative emotional experiences suffered by law students in their classes, but they would also consider the potential benefit of positive emotional experiences on law students in those same classes. But that possibility is largely ignored. Rather, authors of more recent law and emotion literature typically write about a specific emotion, such as disgust, shame, or fear, and whether law should take that emotion into account, ${ }^{39}$ or they analyze a legal doctrine or legal determination, such as victim impact statements or capital sentencing, and consider how the law uses or should use emotion in its decision, ${ }^{40}$ or they focus on legal actors, such as jurors, judges, or lawyers and how emotions affect their decisionmaking. ${ }^{41}$

Some writers have advocated that clinical course offerings be expanded so that students can develop the emotional skills necessary for them to become competent in affective and interpersonal matters that they will confront as practicing attorneys. ${ }^{42}$ Others have suggested that professional

the daily exercise of a license to inflict pain"); Watson, supra note 7, at 109 ("I will not go so far as to use the word sadistic to describe [the feeling experienced by professors teaching first-year classes], but there can be no doubt that they are enjoying their work. They view their task as nearly a holy mission to root out all ill-conceived and unreasoned attitudes in their students.”).

38. See, e.g., Watson, supra note 7, at 123 (asserting that "the Socratic teacher, ... in the eyes of the student, tends to turn into an enemy").

39. See Maroney, supra note 7, at 125-26 (citing authorities).

40. Id. at 129-30 (citing authorities); see also Susan A. Bandes, Repellent Crimes and Rational Deliberation: Emotion and the Death Penalty, 33 VT. L. REV. 489, 511-18 (2009); Susan A. Bandes, Victims, “Closure," and the Sociology of Emotion, LAW \& CONTEMP. PROBS., Spring 2009, at 1, 9-25; Douglas A. Berman \& Stephanos Bibas, Engaging Capital Emotions, 102 Nw. U. L. REV. COLLOQUY 355 (2008), http://colloquy.law.northwestern. edu/main/2008/06/engaging-capita.html.

41. Maroney, supra note 7, at 131-33 (citing authorities); see also Todd E. Pettys, The Emotional Juror, 76 ForDHAM L. REV. 1609 (2007). For a proposed taxonomy for all law and emotion scholarship, see generally Maroney, supra note 7, at 125-33.

42. Alan M. Lerner, Using Our Brains: What Cognitive Science and Social Psychology Teach Us About Teaching Law Students To Make Ethical, Professionally Responsible, Choices, 23 QuinNiPIAC L. Rev. 643, 694 (2004) ("Clinics, in which the students represent clients in real matters under the close supervision of experienced lawyers/teachers, thus provide a quintessential locale for emotional engagement of law students in factually complex matters, challenging them to identify and grapple with issues of professional responsibility.”); John E. Montgomery, Incorporating Emotional Intelligence Concepts into Legal Education: Strengthening the Professionalism of Law Students, 39 U. TOL. L. REV. 323, 350 (2008) (suggesting that instruction on emotional intelligence "can be incorporated into substantive courses that have a skills component or into skills courses [such as Negotiation], which are a better fit”); Deborah L. Rhode, 
responsibility should be taught pervasively throughout the curriculum so that students are provided with frequent opportunities to express their "emotional attitudes toward the ideals, tasks, goals, and problems of the legal profession." "33 In its 2007 monograph, Educating Lawyers, the Carnegie Foundation for the Advancement of Teaching proposed that legal education focused on practical skills and professional identity be elevated to the same level as education for legal analysis. ${ }^{44}$ By doing so, a holistic educational experience is created, integrating the cognitive, the practical, and the ethical-social elements of legal education. ${ }^{45}$

I also believe that emotional issues confronting lawyers in "real" practice should not be deferred until students' second or third year of law school. Those issues are an essential part of practical skills and professional identity development. In the typical first-year lawyering skills course, students learn how to perform legal research and write a memorandum of law in their first semester. In their second semester, they write an appellate brief and make an appellate moot court argument. Such a narrow focus does not adequately introduce students to emotional issues they are likely to encounter in dealing with clients, witnesses, jurors, judges, other attorneys - and themselves-in the practice of law. Nevertheless, without restructuring an already crowded lawyering skills

Missing Questions: Feminist Perspectives on Legal Education, 45 StAN. L. Rev. 1547, 1563 (1993) (urging law schools to commit "to more cooperative, collaborative, and empathetic lawyering" that would be achieved through "much greater emphasis [on] legal clinics, simulations, pro bono programs, and other settings for interactive, experiential learning"); Edward Rubin, What's Wrong with Langdell's Method, and What To Do About It, 60 VAND. L. REV. 609, 662-63 (2007) (bemoaning the fact that skills training and clinical education "are not integrated with the lecture classes, and they have been marginalized by their later introduction into the curriculum and by the norms of the professoriate"); Silver, supra note 7, at 1174 (suggesting that skills courses, such as counseling, negotiation, and drafting, provide an opportunity to prepare students for the emotional dimensions of lawyering).

43. Andrew S. Watson, Some Psychological Aspects of Teaching Professional Responsibility, 16 J. LEgAL EDUC. 1, 20 (1963); see also Joshua E. Perry, Thinking Like a Professional, 58 J. LEGAL EDUC. 159, 164 ("[A] legal pedagogy focused on a hard 'think like a lawyer' mentality unleavened by a mushy 'think like a professional' sensibility threatens to produce legal professionals incapable of balancing the complex demands of personal well-being and professional service.”).

44. SULLIVAN ET AL., supra note 6, at 12-15.

45. Id. at 191. See James R. Maxeiner, Educating Lawyers Now and Then: Two Carnegie Critiques of the Common Law and the Case Method, 35 INT'L J. LEGAL INFO. 1 (2007) (comparing the 2007 Carnegie Foundation Report to the 1914 Carnegie Foundation Report prepared by Josef Redlich). Another report on legal education, also published in 2007, recommended: "Law schools should organize their curriculums to develop knowledge, skills, and values progressively; integrate the teaching of theory, doctrine, and practice; and teach professionalism pervasively throughout all three years of law school.” ROy STUCKey, BESt PRACTICES FOR LEGAL EDUCATION 8-9 (2007). 
course, first-year law students can be introduced to these issues if professors teaching substantive first-year courses devote at least some time to them in their courses.

Unfortunately, most legal educators have not fully appreciated "the insight offered by cognitive science that emotion plays a vital, critical role in normal adaptive reasoning. ${ }^{, 46}$ But even authors who urge professors to alter their teaching styles and to integrate emotional issues into class discussion do not provide examples for professors to emulate. Some write in generalities. A professor, we are informed, can show students "the complex interplay of emotion, logic and aspiration in legal analysis and lawyering. He [or she] can lead them through the struggle to assimilate complexity and respond creatively, the hallmarks of adaptive intelligence which he [or she] has cultivated over time." ${ }^{, 47}$ Other authors urge professors to analyze emotions, asserting, "[O]ur view of reason and emotion as complementary elements of thought requires us not just to allow emotions into the classroom, but to learn how to examine them, learn from them, and incorporate them into rational argument." 48

Educating law students about emotions should begin in the first year of legal education. ${ }^{49}$ However, I question whether it is necessary, or even advisable, to engage in an intellectual analysis of emotional issues in first-year law classes. Rather, I want students to actually experience emotion in the classroom setting as they discuss various fact situations and the legal principles involved in the resolution of disputes involving those facts. After all, fact situations, even when studied in the context of appellate court decisions, are created by people. Those people are judged by other people-judges and juries. Law students need to understand

46. Coleburn \& Spring, supra note 7, at 23. Coleburn and Spring added: "Moreover, without the development of emotional skills such as empathy, reflectiveness, and tolerance of disappointment, which allow the grey area thinking needed to appreciate complexity, conflict resolution is impossible, and 'knowledge is built on sand."' Id. at 23-24.

47. Id. at 37; see also Rhonda V. Magee, Legal Education and the Formation of Professional Identity: A Critical Spirituo-Humanistic- "Humanity Consciousness"Perspective, 31 N.Y.U. Rev. L. \& Soc. ChAnge 467, 476 (2007) ("We should talk about the spiritual and emotional implications of what we study, what we do, and how we interact with one another, so as to encourage and to model an approach to legal education and practice that brings the whole person into the room.”).

48. Harris \& Shultz, supra note 7, at 1787.

49. See Lerner, supra note 42, at 704 ("What we omit, as what we include in the first year curriculum, sends an implicit, but readily learned, message about what we think-no, what we 'know'-is important for lawyers to do, and therefore for law students to learn.”). 
and appreciate the emotions of people, including their own emotions, if they are to become the best lawyers they are capable of becoming. In the next Part of this Article, I present specific examples from my firstyear Torts course in which I raise issues in a manner that results in an emotional response by students. I demonstrate how such methodology stimulates class discussion, increases student interest, and enriches the educational experience. I hope that by providing such examples, I will be able to convince other professors to modify their courses so that their students will not only learn more, but they will also be more satisfied by the instruction they receive.

\section{EXPERIENCING EMOTION: EXAMPLES FROM A TORTS CLASS}

"The life of the law has not been logic: it has been experience."

\section{A. The First Question}

As a part of the orientation program for first-year law students at my law school, a simulated class session is conducted in each section, taught by a professor who teaches a course to those students. The session is entitled: "Demystifying the Socratic Method." I always volunteer to teach that class. ${ }^{51}$ For this special session, I assign three torts cases to the students. Students are informed that the class will be conducted as a regular class session in Torts and that they are expected to be fully prepared on the assignment for this class.

To begin the class, I call upon a student-let us assume her name is Courtney-and inform her that I feel confident that she, as a first-year law student experiencing her first real law school class, is fully prepared on the assignment for the day. Therefore, I am giving her the privilege, the distinct honor, of answering the first substantive question that will be asked in law school of anyone in her class. I pause for a moment for the enormity of the event to sink in, and then I ask: "What is the difference between a jeweler and a jailor?" I then add: "I know this is a difficult question, in fact, it's a real conundrum, but do the best you can."

Typically, the responding student will tell me that a jeweler makes or sells jewelry and that a jailor runs a jail or keeps prisoners locked up. I respond by saying, "That's not bad for a first answer. If this was a

50. O.W. Holmes, The COMmon LAW 1 (1881). Consider also this well-known saying: "Experience is the best teacher."

51. In schools that do not offer such an opportunity as a part of the orientation program, a professor can teach his or her first class session using the methodology that I use in the orientation class session. 
question on your final examination, I would probably award you a grade of $\mathrm{D}^{+}$, or maybe even a C- if I was feeling generous. However, if you want to know the 'right' answer-the answer that would earn you a grade of A or A+, I'll tell you. A jeweler sells watches; a jailor watches cells.

"I know that you are all asking yourselves: what is the relevance of this question; what is its significance to our study of law? And I will tell you. Before the jeweler sells those watches, he must either own them or have been authorized by the owner to sell them. That's the law of personal property that you study in your Property course. And if he sells those watches, that's a contract for the sale of goods-offer, acceptance, consideration-which you study in your Contracts course. But if the prisoner who the jailor is watching is in his cell because he stole those watches before they were sold, that's the crime of larceny, which you study in your Criminal Law course. However, before the thief can be convicted of a crime, he must undergo a criminal trial in which he is accorded certain rights - the right to a trial by a jury of his peers, the right to be represented by an attorney, the privilege against selfincrimination-which you will study in your Constitutional Law course. And if the rightful owner of those watches sues the thief to reobtain that property or to be paid for the damage done to those watches, that is the tort of conversion-the thief wrongfully converted the property to his own use-which you will study in your Torts course. And in a civil trial, in which the rules of civil procedure will be applied, the thief will be found liable for the tort. You will study those rules in your Civil Procedure course.

"Just think. If only Courtney had been able to answer this question correctly, we would have completed all of the courses in the first year of law school, and we could have moved on today to the second year. I could have saved each of you over $\$ 40,000$ in tuition and a full year of law studies. Unfortunately, however, Courtney did not give me the correct answer. So I guess we'll just have to spend a whole year on those courses.

"I know what you are thinking. Professor Morris's first question surprised us, his answer to that question was clever, and his explanation of the significance of the answer to the study of law was extremely insightful. We are so fortunate to have such a brilliant professor to teach us Torts! But we have a question that still lingers in our minds. Obviously, Professor Morris's excellent answer deserved a grade of A+. 
However, as the kind, caring, compassionate people we are, we are concerned about our colleague, Courtney. Was Professor Morris too harsh in grading Courtney's answer a D+ or even a C-? After all, there was nothing in the assignment that we read that would prepare us for that question. Courtney's answer was as good an answer as any of us would have been able to give. Shouldn't she at least receive a grade of $\mathrm{B}$ or $\mathrm{B}+$ ?

"Well, I'll tell you why I didn't give Courtney a higher grade on her answer. Courtney did not take advantage of the clue I gave her-the hint that would enable her to give a better response to my question. Do you remember what I said after I asked Courtney the first question?” I usually wait for a response but seldom receive one. "I informed Courtney, and the rest of you, that the question I was asking was a difficult question, in fact, it was a real conundrum. What is a conundrum?" I then take the dictionary that I brought to class and hand it to a student sitting directly in front of me. I ask the student to look up the definition of conundrum and read it to the class. The student does so and reports: "conundrum: a riddle whose answer contains a pun (Ex.: 'What's the difference between a jeweler and a jailer?' 'One sells watches and the other watches cells.')."52

I then say: "So you see, I didn’t just make up that question. You never know where you will find your source of law! Let me summarize all you have accomplished in your first five minutes of law school: You have learned the difference between a jeweler and a jailor. You have learned the significance of that difference to the study of law. You have learned that in this class we work together to support our colleagues. You have learned that although I may be a tough grader on examination questions, nevertheless, I try to be fair and to have some supportable basis for the grades that I award. You have learned the importance of words to law and to lawyers-even a word such as conundrum. Words are our tools, our only tools, in talking to clients, in drafting legal documents, in making arguments to a judge or jury. When you read the cases in your coursebook, you should closely examine the words used by the judge who wrote the opinion you are reading. Those words inform you of the judge's reasons for the decision that he or she made. And finally, you learned that to demystify the Socratic method, you must first mystify it. You learned all that in just five minutes in this class. Isn't law school wonderful?”

52. Webster's New World Dictionary of the American Language 310 (David B. Guralnik ed., 2d college ed. 1970). 
What emotions did my students experience in their first five minutes of class? When class first began, the students were excited to have their first class, but they were also a bit nervous, apprehensive about the questions I would ask and their ability to answer them. When I asked my first question, the students were surprised-the question had nothing to do with the material that had been assigned. Was I merely joking, or did I really want that question answered? When I awarded Courtney's answer a grade of $\mathrm{D}+$ or $\mathrm{C}-$, they were fretful, concerned about my announcement of a grading standard that would make it impossible for them to succeed. When I gave my answer to that first question, they laughed-although some may have groaned. When I explained the significance of my answer, they were intrigued that I could fit all of the first-year courses into that one answer. When I explained that Courtney did not use the clue I provided to her, they were incredulous - they had no idea that my clue was the use of the word conundrum. When the student read the dictionary definition of conundrum, the students were surprised to learn that my question had come from an example of a conundrum contained in the dictionary that I had provided.

I believe that humor, if appropriately timed and in appropriate doses, is an effective tool to lessen anxiety and relieve tension that students experience as they commence their legal education. ${ }^{53}$ Having achieved that goal in the first five minutes of class, my students were now emotionally ready to begin analyzing the cases that had been assigned for class discussion.

\section{B. Intentional Infliction of Emotional Distress}

When we study the tort of intentional infliction of emotional distress, we begin with a discussion of State Rubbish Collectors Ass'n v. Siliznoff. ${ }^{54}$ In that case, Siliznoff was pressured to sign a note agreeing to pay the Association for the privilege of collecting rubbish from a customer who had previously been serviced by a member of the

53. See Hess, supra note 7, at 105 (suggesting that humor by a professor enhances the classroom experience, provided that the humor is not at the expense of a student); Levy, supra note 20, at 82 (asserting that students appreciate humor by their professor to make the class entertaining).

54. 240 P.2d 282 (Cal. 1952). I use the Prosser casebook for my Torts class, and therefore, cases discussed in this Article are found in that casebook. VICTOR E. SCHWARTZ ET AL., PROSSER, WADE AND SCHWARTZ's TORTS (11th ed. 2005). 
Association. If he did not agree to sign and pay the note, he was told that he would be beaten up and forced out of business. ${ }^{55}$ The Association's conduct did not constitute the tort of assault because it threatened only future harm and did not place Siliznoff in apprehension of imminent harmful bodily contact. Nevertheless, the California Supreme Court ruled that by making a serious threat to Siliznoff's physical well-being, the Association's conduct was sufficiently reprehensible to constitute the recently created tort of intentional infliction of emotional distress. ${ }^{56}$

Students then read the case of Slocum v. Food Fair Stores of Florida, Inc. ${ }^{57}$ In Slocum, the plaintiff, a customer in a food store, sued for the mental suffering and ensuing heart attack she allegedly had suffered, caused by insulting language directed toward her by the defendant's store clerk. Specifically, in reply to the plaintiff's inquiry as to the price of an item he was marking, the clerk replied: "If you want to know the price, you'll have to find out the best way you can. You stink to me."58 The trial court dismissed the complaint for failure to state a cause of action, ${ }^{59}$ and the Florida Supreme Court affirmed. ${ }^{60}$ The case stands for the proposition that the tort of intentional infliction of emotional distress requires an intent on the part of the defendant to inflict severe emotional distress. Thus, insulting language, which is intended to inflict only mere emotional distress, is not actionable. ${ }^{61}$

I typically ask the class whether they agree with the decision that seeks to place a reasonable limit on liability for this tort. The students invariably agree with the decision. After all, it is early in the semester and they have the reasoning of the Florida Supreme Court as their authority. I then ask, "How did the court characterize the defendant's conduct, his insult, in this case?” I point them to specific language in the court's opinion in which the court declares that the defendant's insult was "innocuous." ${ }^{2}$ I then ask them for the definition of innocuous. Webster's defines innocuous as "harmless.", ${ }^{\prime}$ I then ask, "But didn't the plaintiff allege that as a result of the insult, she suffered a heart attack? Is conduct that causes a heart

\footnotetext{
55. State Rubbish Collectors Ass'n, 240 P.2d at 284.

56. Id. at 285.

57. 100 So. 2 d 396 (Fla. 1958).

58. Id. at 396-97.

59. Id. at 396.

60. Id. at 398.

61. Id. at 397.

62. Id. at 398 .

63. WEBSTER's New WORLD Dictionary of the AMERICAN LANGUAGE, supra note 52, at 726 (defining innocuous as "that does not injure or harm; harmless"). Yes, I bring my dictionary to class in the event that the student who is called upon misdefines
} the word. 
attack harmless conduct?" They are stunned. I then ask: "Do you think the court just didn't believe the plaintiff's claim that she suffered a heart attack from the insult she received?" They readily agree. I then respond: "Well, let me tell you. I went back and researched this case very carefully. And I want you to know, Mrs. Slocum-Mrs. Julia Slocum-did suffer a heart attack that was caused by the defendant's insult. I know this to be true. The court knew this to be true. And you know this to be true!"

"How do you know this?" I ask. If they are unable to come up with the answer, I ask them to consider the procedural posture of the case. The court affirmed the ruling of the trial court that dismissed the complaint for failure to state a cause of action. In essence, the court did not give the plaintiff an opportunity to present evidence to prove her claim because even if she was able to establish the facts as she alleged them to be, the applicable law would not support recovery by her. To make such a ruling - to deprive the plaintiff the opportunity to offer evidence in support of her claim - the court must assume that the plaintiff would be able to prove the facts that she alleged. Here, to throw the plaintiff out of court without giving her the opportunity to offer evidence, the court must assume that she suffered a heart attack caused by the defendant's insult.

"How is it possible to say that conduct that causes a heart attack is innocuous conduct?” I ask. Usually the students are too flabbergasted to answer the question. If they do not, I suggest: "How about the argument that the defendant only intended to insult Mrs. Slocum, but he did not intend to cause her to suffer a heart attack? Does that make his conduct innocuous and not subject to tort liability?" After a brief discussion of this possibility, I ask: "Assume a practical joker pulls a chair out from under the plaintiff intending for the plaintiff to fall to the floor without suffering any injury other than the offensive contact with the floor. But suppose the plaintiff suffers an injury to his or her spine or a broken leg. Can the defendant avoid liability for the tort of battery by establishing that he intended only offensive contact but not harmful contact?" Having recently studied the tort of battery, the students know that liability will be imposed. I then inform them that unlike any other intentional tort that we have studied, or that we will study, a defendant who is charged with the tort of intentional infliction of emotional distress will be able to avoid liability by establishing that he only 
intended to cause a small injury — mere emotional distress — instead of a big injury-severe emotional distress.

"But perhaps," I suggest, "there is another argument that can be made to support the court's decision to nonsuit the plaintiff." I then ask: "Why do you suppose the store clerk insulted the customer; why did he say: 'You stink to me.'?" Typically, a student will respond that perhaps she really did smell bad. To this assertion, I respond: "In other words, he told the truth. For the torts of libel and slander, truth is a complete defense. If I say or write something injurious to the reputation of the plaintiff, for example, I accuse him of engaging in illegal or immoral activity, I can avoid tort liability by establishing that I spoke the truth. Should truth also be a defense to an action for the tort of intentional infliction of emotional distress?" While they are thinking about this question, trying to determine how to respond, I move away from the podium and address them directly:

Ladies and Gentlemen of the jury: The defendant says he told the truth. He seeks to cloak himself in a mantle of truth-to shield himself from liability by hiding behind a facade of truth. But I will tell you another truth. My client, Mrs. Slocum-Mrs. Julia Slocum-was an elderly, homeless woman in a weakened physical condition, living on the streets of our city. She had no comfortable bed on which she could rest her weary bones at night. She had no shower to cleanse her filthy body. Yes, she was poor-but she was honest! And after she had scrimped and saved enough money to buy a can of beans to sustain her humble existence for yet another day, she walked proudly into that Food Fair store prepared to make her purchase. And when she did so, she was entitled to be treated with the respect that you or I or any other customer in that store is entitled to be treated.

The truth, ladies and gentlemen, is that this is a case about robbery. When the defendant's clerk insulted Mrs. Slocum, he robbed her of her health. You have heard the testimony of three extremely reliable eye witnesses-a priest, a rabbi, and a minister-who were attending an interfaith ecumenical convention in our city and who just happened to be in that store at the time of the incident. They informed you that they overheard the defendant insult Mrs. Slocum and saw her clutch at her chest and immediately collapse in response to the clerk's remark. You have heard the testimony of forensic experts who informed you that given the timing of this sequence of events, the inescapable conclusion is that Mrs. Slocum's heart attack was directly caused by the clerk's gross insult.

But that is only part of the injury that Mrs. Slocum suffered. When the defendant's clerk insulted Mrs. Slocum, he not only robbed her of her health, he also robbed her of her dignity, her pride, her self-respect. As a customer in that store, she was entitled to receive respectful treatment. She did not receive it! I call upon you, ladies and gentlemen of the jury, as the representatives of a decent and civilized society, to say to this defendant: "We are outraged! We will not allow you to insult with impunity our sister. When you insulted Mrs. Slocum, you insulted us. When you harmed her, you harmed us. You have done wrong, and for the injury caused by your transgression, you must pay!”

Suddenly, the discussion develops a whole new tone. No longer is this a silly little case about some greedy plaintiff represented by some 
unscrupulous attorney who is seeking money damages for a perceived insult. Mrs. Slocum is not merely a name in an appellate case. She is a flesh and blood person who is entitled to be treated with the same respectful treatment that we all wish to be accorded. The students empathize with her. They are angered-outraged-by the employee's insensitivity. No longer is Mrs. Slocum viewed as someone who is seeking to recover for a trivial or nonexistent mental affront. She claims that she suffered a heart attack as a direct result of the insulting language, and she presented convincing evidence that her claim was genuine.

My closing argument was addressed to my students sitting as jurors, not as law students. They were not asked, as future lawyers, to develop an argument that would appeal to jurors. They were not asked to intellectually analyze the strength of the argument I presented. At least initially, they reacted emotionally as jurors in the case. The question to be asked was whether, if the case had gone to trial and they were jurors who heard the evidence that I said was presented, they would have ruled for the plaintiff? The answer was a resounding "yes.” Only after they experienced an emotional response to my closing argument, would I allow the class to return to other issues: Was it appropriate for the court to dismiss her claim even if the defendant's insult actually caused such a severe injury? Was she really homeless, and could she prove that she suffered a heart attack? Did the professor make up the facts? I inform the class that because the court dismissed the plaintiff's complaint for failure to state a cause of action, it was appropriate for me to assume that the plaintiff could prove what she alleged and to make up facts that would most strongly support her claim.

Finally, to complete our discussion, I explain why I made this impassioned closing argument to the jury. First, I wanted to demonstrate to the class that while we talk about the legal principles that decide appellate cases, they need to understand that lawsuits deal with real people and the problems they face. Second, I wanted to demonstrate the significance of a court order dismissing a complaint for failure to state a cause of action. The court is ruling as a matter of law that even if the plaintiff is able to prove what he or she alleges to be the facts, the law does not support the plaintiff's winning the case. No matter how strong the evidence supporting the plaintiff's claim, the plaintiff loses on a point of law. So I wanted to present the class with the type of evidence that the plaintiff might be able to present if the court allowed the plaintiff's claim to proceed and to demonstrate just how powerful that evidence could be if the jury were 
permitted to decide the case. Third, I wanted to demonstrate the significance of legal arguments. I had previously suggested to the class that in the future, courts may be willing to extend the duty of courtesy owed by common carriers and hotels to other businesses open to the public. After all, the Civil Rights Act of 1964 requires all places of public accommodation to serve customers without discrimination based on race, color, religion, or national origin. ${ }^{64}$ That law imposes this duty of service not only on common carriers and hotels but also on restaurants, movie theaters, sports arenas, and other places of exhibition or entertainment. If in the future, courts extend a duty of courtesy to all businesses open to the public, then I as a trial attorney have a powerful argument to make to the jury on behalf of my client, Mrs. Slocum, particularly if I am able to prove that she suffered some really significant injury, such as a heart attack. She was not treated with the courtesy and respect that was owed to her as a customer in the defendant's store.

\section{Negligence: The Applicable Standard of Care}

\section{The Reasonable Person Standard: Gender Neutral or Gender Specific?}

In Vaughan v. Menlove, ${ }^{65}$ decided in 1837, the Court of Common Pleas adopted the reasonable man test as the standard of care to determine whether a party acted negligently. The casebook authors note that although historically the masculine gender was used, "[o]bviously, this form of description is now outdated. The form used [today]... is the reasonable, prudent person.”66

I raise the highly emotional issue of whether men and women should be held to the same standard of care or whether the standard should be gender specific. To do so, I begin by reading an excerpt from A.P. Herbert, who wrote a whimsical description of "the Reasonable Man."67 Herbert tells us that "[h]e is an ideal, a standard, the embodiment of all

64. 42 U.S.C. § 2000a(a)-(b) (2006). I suggest to the class an alternative explanation for the insult to Mrs. Slocum. Perhaps she was not a homeless person, but rather, was an African American person who the clerk did not want to serve in the store. After all, the incident occurred in the Deep South-Florida-and the Supreme Court of Florida issued its opinion in 1958 - six years prior to the enactment of the Civil Rights Act of 1964.

65. (1837) 132 Eng. Rep. 490 (Ct. Com. Pl.).

66. SCHWARTZ ET AL., supra note 54, at 148 .

67. A.P. HERBERT, UNCOMMON LAW 1-6 (10th prtg. 1964). 
those qualities which we demand of the good citizen.”68 After giving numerous examples, Herbert asserts:

Devoid, in short, of any human weakness, with not one single saving vice, sans prejudice, procrastination, ill-nature, avarice, and absence of mind, as careful for his own safety as he is for that of others, this excellent but odious character stands like a monument in our Courts of Justice, vainly appealing to his fellow-citizens to order their lives after his own example. ${ }^{69}$

But then comes the shocker. Herbert writes: "[I]n all that mass of authorities which bears upon this branch of the law there is no single mention of a reasonable woman." ${ }^{70}$ Male students in the class are amused; female students are offended. I tell the class that if I ask the men why women do not find the statement amusing, they will respond that women do not have a sense of humor. If I ask the women why men are not offended by the statement, they will respond that men are jerks.

I then dare to ask what I describe as the unaskable question: "Should women be held to a different standard of care than men? In other words, should the reasonable person standard be gender specific? Consider, for example, the everyday act of driving a car. Should women drivers be held to the standard of the reasonable woman driver or to the standard of the reasonable person driver?" After we engage in a brief discussion of this issue, I then say, "I'm going to offer you some evidence that you may wish to consider in deciding the appropriate standard of care to be applied to women drivers." The "evidence" that I offer comes from three newspaper articles, ${ }^{71}$ one written in 1975, one in 1998, and one in 2007. The 1975 article is entitled Male Drivers Make More Errors, and it states:

Men drivers tend to overrate their own abilities and make driving errors because of that rating, while women are fairly accurate in describing their driving, a study by a research firm here showed.

68. Id. at 2 .

69. Id. at 4

70. Id. at 5 .

71. I frequently use newspaper articles to make a point to the class. When I hold up a newspaper article and read from it, the students pay close attention. A newspaper article, written by laypersons about some event or facts that do not directly involve a court decision, offers a welcome respite from the rather sterile recitation of facts typically found in appellate court opinions. And yet, I am able to use the article to provide information that is pertinent to our discussion of a legal issue. 
The $\$ 100,000,18$-month study by Capspan Corp. concluded that men tend to drive faster and more aggressively than women because they think they are better drivers, study director Roy S. Rice said.

But Rice said the study of 100 drivers in all age groups showed that the men who drove the most aggressively also failed more driver tests.

Surprisingly, it was not the youngest male drivers who were most aggressive and drove fastest, but the male drivers from 25-45 years old, Rice said. The researcher said men under 25 ranked second to the middle group in aggressiveness and errors. Older men ranked third, followed by young women, middle-aged women and older women, he said.72

The 1998 article is entitled Men and Driving: They Just Don't Mix, and it begins as follows:

If you must drive, don't drink testosterone.

That stuff could be the most dangerous substance being abused on the highways today.

Either that or men are just awful drivers. Maybe they're not equipped for handling big, fast, internal combustion vehicles.

It turns out that male drivers are-statistically-a greater menace than female drivers by far to everybody on the road, including themselves.

$\ldots$.

Men account for little more than 50 percent of licensed drivers and women for just more than 49 percent-close to an even split-but the risk of being involved in a fatal crash is three times higher for males.

$\cdots$

Here's a reason: Of the men involved in fatal crashes, 28 percent had bloodalcohol concentrations of .01 or greater (meaning some alcoholic drinking) compared with 15 percent of women.

And another 21 percent of men in these accidents had blood-alcohol readings of .10 or greater (meaning they were legally drunk) compared with 11 percent of women drivers.

"Proportionally, twice as many males were legally drunk as females," says Alan Hoskins, a statistician with the National Safety Council. "Among younger male drivers especially, the combination of two substances, alcohol and testosterone, is pretty deadly."73

The 2007 article is entitled Road Risk Higher for Male Drivers, and it begins as follows: "That age-old stereotype about dangerous female drivers is shattered in a big, new traffic analysis: Male drivers have a 77 percent higher risk of dying in a car accident than women, based on miles driven."74

Suddenly, the tables have been turned. Now the women have the upper hand. I revise the inquiry: "Perhaps, instead of focusing on women drivers,

72. Male Drivers Make More Errors, EvENING TRIB. (San Diego), July 7, 1975, at D5.

73. John Lang, Men and Driving: They Just Don't Mix, SAN DiEGo Union-TriB., July 19, 1998, at D3.

74. Seth Borenstein, Road Risk Higher for Male Drivers, SAN DIEGo UnION-TRIB., Jan. 19, 2007, at A1. 
we should be asking whether men drivers should be held to the reasonable man driver standard or whether they should be held to the higher standard of the reasonable woman driver. After all, if that higher standard is applied, we can achieve the socially beneficial result of significantly fewer auto accidents and the deaths and injuries that occur in those accidents."

After an extended discussion of this proposal, I give an explanation of why I believe the gender-neutral, reasonable person standard is applied in negligence cases. Although the reasonable person only exercises reasonable care, he or she exercises that care all the time. In determining the appropriate conduct in any situation, society asks what a reasonable person would do, not what men or women actually do in that situation. In driving a car, a reasonable person would obey the posted speed limit, would signal turns, would not be distracted by a cell phone, radio, or conversation with passengers, and would not drive after drinking alcohol. The reasonable person is a hypothetical being who never acts negligently. Perhaps that is what A.P. Herbert was describing when he said that the reasonable person is "devoid ... of any human weakness." 75 The reasonable person "is an ideal, a standard, the embodiment of all those qualities which we demand of the good citizen.,"76

\section{The Reasonable Person Standard Contrasted with the Economic Person Standard}

In United States v. Carroll Towing Co., ${ }^{77}$ Judge Learned Hand explained in algebraic terms when an actor is negligent. If the burden of precaution to avoid the injury is less than the gravity of the injury multiplied by the probability of its occurrence, the actor who fails to take that precaution has acted negligently. ${ }^{78}$ Law and economics scholars

75. HERBERT, supra note 67 , at 4 .

76. Id. at 2 .

77. 159 F.2d 169 (2d Cir. 1947).

78. Id. at 173 ("[L]iability depends upon whether B is less than $\mathrm{L}$ multiplied by $\mathrm{P}$ : i.e., whether B < PL.”). In Moisan v. Loftus, 178 F.2d 148, 149 (2d Cir. 1949), Judge Hand presented a revised formula: "It is indeed possible to state an equation for negligence in the form, $\mathrm{C}=\mathrm{P} X \mathrm{D}$, in which the $\mathrm{C}$ is the care required to avoid risk, $\mathrm{D}$, the possible injuries, and $\mathrm{P}$, the probability that the injuries will occur, if the requisite care is not taken.” Judge Hand cautioned, however, that the factors cannot be measured precisely, and that attempts to do so "are illusory; and, if serviceable at all, are so only to center attention upon which one of the factors may be determinative in any given situation.” Id. 
have used Judge Hand's formula to determine when it is economically appropriate to find an actor negligent. Judge Richard A. Posner, in an article that my students read, writes: "[T]he dominant function of the fault system is to generate rules of liability that if followed will bring about, at least approximately, the efficient—the cost-justified-level of accidents and safety.",79

In a class devoted to exploring Judge Hand's formula and the propriety of a law and economics approach that equates the economic person with the reasonable person-inefficiency equals blameworthiness-we discuss excerpts from an article entitled The Positive Economic Theory of Tort Law, written by William M. Landes and Richard A. Posner. ${ }^{80}$ The authors analyze Eckert v. Long Island Railroad Co., ${ }^{81}$ translating the court's opinion into economic terms. In Eckert, a jury found that the defendant's train was traveling at excessive speed in a highly populated area, and its swift approach imperiled a young child sitting or standing on the tracks. Plaintiff's intestate attempted to rescue the child but was struck by the train and killed. ${ }^{82}$ In determining whether the railroad should be held liable for its negligence or whether the deceased's conduct constituted contributory negligence that would bar recovery, the authors, applying an economic analysis, ask whether the railroad would have decided to "buy" the rescuer's services. Assuming that the child's life and the rescuer's life have roughly the same value, the question of whether the rescuer was contributorily negligent becomes a question of whether the rescuer probably could have saved the child without serious injury to himself. ${ }^{83}$

I ask students whether courts should be making decisions this way. For example, suppose there is an old, feeble person who is imperiled on the tracks due to the railroad's running its train at excessive speed in a densely populated area. Do we want the court to determine whether a person who attempts to rescue the old person is contributorily negligent by asking whether the negligent railroad would have decided to buy the potential rescuer's services? Arguably they would not because the value of the old person's life may be significantly less than the potential rescuer's life.

79. Richard A. Posner, A Theory of Negligence, 1 J. LEGAL STUD. 29, 33 (1972). Judge Posner also wrote: "[A] negligence standard of liability, properly administered, is broadly consistent with an optimum investment in accident prevention by the enterprises subject to the standard.” Id. at 30.

80. William M. Landes \& Richard A. Posner, The Positive Economic Theory of Tort Law, 15 GA. L. REV. 851, 896-98 (1981).

81. 43 N.Y. 502 (1871).

82. Id. at 503-04.

83. Landes \& Posner, supra note 80, at 897-98. 
I pose the fundamental question: "Should all human life be valued equally or should some lives be considered more valuable than others?" Students are troubled by the inquiry. Our Declaration of Independence heralds the self-evident truth that we are all created equal. And yet, what if in my hypothetical there are two railroad tracks and the rescuer could save either the old person or the child? Who would society want him to save? What if there is an auto accident and two people suffer a similar injury? If they are brought to a hospital that has a machine that can save the life of either the old person or the child, how does the hospital decide who gets the one machine-flip a coin? I also read a newspaper article to the class that is entitled Age Called Factor in Heart Treatment, which begins as follows: "People over age 75 are significantly less likely than younger patients to receive certain life-saving treatments for heart attacks, researchers ... have found." ${ }^{84}$ The article reports that a "study of heart-attack patients found that those over age 75 were 12 times less likely than patients under 65 to receive 'clot-busting' drugs to treat their condition, and seven times less likely to undergo the arteryclearing procedure balloon angioplasty." 85 I also read a portion of a more recent newspaper article about the advantages of "[c]oronary stents laced with the new drug sirolimus [that] are far less likely to cause obstructive artery scarring than older, uncoated stents." 86 The article also reports: "But many doctors say the price of the tiny device-five times greater than plain stents-is limiting which patients will get them.",87

As a part of our discussion, I read a brief excerpt from A.P. Herbert's essay in which he compares the reasonable man with the economic man. "This noble creature[, that is, the Reasonable Man,] stands in singular contrast to his kinsman the Economic Man whose every action is prompted by the single spur of selfish advantage, and directed to the single end of monetary gain." ${ }^{88}$ In other words, because the economic person

84. Age Called Factor in Heart Treatment, SAn Diego Union-TriB., Aug. 23, 1994, at A-7.

85. Id.

86. Cheryl Clark, Drug-Coated Stents Less Likely To Lead to Scarring, SAN DIEGO UnION-TriB., Oct. 2, 2003, at B3. Although this article is listed as appearing on B3, the page was erroneously numbered. The article appears on the first page of Section $B$, which should have been numbered B1.

87. Id.

88. HERBERT, supra note 67, at 2 . 
thinks in terms of maximizing profits and reducing costs, that person will employ only the minimum protections necessary to avoid liability. In contrast, the reasonable person does what is right. As applied to my hypothetical based on the Eckert case, the reasonable person, seeing someone-whether a young child or an elderly person-in imminent danger of being struck by a train, would attempt a rescue even if it endangered the rescuer's own life, provided that there was at least some possibility that the rescuer would be able to avoid being killed in the process. Under such circumstances, the rescue attempt would not be foolhardy, and the rescuer would not be found contributorily negligent for making the attempted rescue. ${ }^{89}$ The class engages in an extended discussion of whether Herbert is correct in distinguishing the motivation of the reasonable person - to do what is right - from the motivation of the economic person - to do what is efficient — and whether the result in any case would be the same regardless of the actor's motivation.

The class also discusses Landes and Posner's formulation of how the issue of the rescuer's contributory negligence should be determined, that is, whether the railroad would have decided to "buy" the rescuer's services. The railroad was negligent initially in endangering the child's life. Should society defer to that negligent defendant's judgment as to whether it wished to purchase the rescuer's attempt to rescue, or should society exercise its value judgment to preserve a life in peril by encouraging a potential rescuer to act? Do we really want a potential rescuer to weigh the value of his or her life versus the life of the imperiled victim before deciding whether to attempt a rescue, or do we want that potential rescuer to consider only whether the likelihood of injury or death to himself or herself is so great that it is foolhardy to make a rescue attempt?

\section{The Standard of Care for Physicians}

In studying the standard of care applied to physicians, students learn that the reasonable person standard of care is equated to the standard of practice of the ordinary physician. ${ }^{90}$ In essence, the profession establishes its own standard of care as embodied by the actual practice of physicians

89. See, e.g., Eckert v. Long Island R.R. Co., 43 N.Y. 502, 506 (1871) ("The law has so high a regard for human life that it will not impute negligence to an effort to preserve it, unless made under such circumstances as to constitute rashness in the judgment of prudent persons.”).

90. SCHWARTZ ET AL., supra note 54, at $170 \mathrm{n} .2$ (stating that professionals are expected to possess and exercise "the knowledge, training, and skill (or ability and competence) of an ordinary member of the profession in good standing”). 
generally. Thus, unlike manufacturers of products and businesses who are held to the standard of care of the hypothetical reasonable manufacturer or the hypothetical reasonable business person, ${ }^{91}$ for physicians and other professionals, customary care equals reasonable care. The law's deference to the customary practice of professionals assumes that the customary standard of practice of the profession is sufficiently high to adequately protect people serviced by professionals from misconduct by individual practitioners. In class, I challenge that assumption. I read excerpts from several newspaper articles that I have collected over the years demonstrating that the ordinary physician often adheres to customs that do not incorporate the latest studies and recommended practices. For example, one article is entitled Report Puts Hospital Deaths from Preventable Errors at 195,000 and begins as follows: "The number of hospital patients who die from preventable errors may be twice as high as previously estimated and shows no sign of decreasing .... The findings would make medical mistakes the thirdleading cause of death in the country, behind heart disease and cancer." Another article reports:

Postoperative infections, surgical wounds that accidentally reopen and other often-preventable complications lead to more than 32,000 U.S. hospital deaths and more than $\$ 9$ billion in extra costs annually .... The findings greatly underestimate the problem, since many other complications happen that are not listed in hospital administrative data, the researchers said. 93

After four infants died from a bacterial infection transmitted in a hospital, a newspaper reported:

Surveys consistently show that less than half [of doctors and other health-care workers] routinely wash up, even though "Clean hands are the single most important factor in preventing the spread of dangerous germs and antibiotic resistance in healthcare settings," according to the U.S. Centers for Disease Control and Prevention. Further, it says, "Each year nearly 2 million patients in the United States get an infection in hospitals, and about 90,000 of these patients die as a result.”

$\cdots$

91. See, e.g., Tex. \& Pac. Ry. Co. v. Behymer, 189 U.S. 468, 470 (1903) ("What usually is done may be evidence of what ought to be done, but what ought to be done is fixed by a standard of reasonable prudence, whether it usually is complied with or not.”).

92. Scott Allen, Report Puts Hospital Deaths from Preventable Errors at 195,000, SAn Diego Union-TriB., July 27, 2004, at A6.

93. Lindsey Tanner, Annual Death Toll from Post-Surgery Complications Put at 32,000, SAN DieGo Union-TriB., Oct. 8, 2003, at A15. 
But the problems of customary medical practice are not limited to injuries and deaths in hospital settings. One newspaper article reported: "One after another, blockbuster-selling drugs are being yanked off the market for killing or injuring Americans. Many were banned because doctors ignored safety warnings and prescribed them to the wrong patients ...."95 Another article reported:

Cholesterol-lowering drugs known as statins that can help prevent heart disease remain under-prescribed for many at-risk patients . . . .

$\ldots$...

"Only 50 percent of high-risk patients who visit doctors receive statins," said study author Dr. Jun Ma, a research associate at the Stanford Prevention Research Center. "People may die prematurely because of inadequate treatment."96

Three years ago, an article in Parade magazine identified misdiagnosis as the most dangerous medical mistake. ${ }^{97}$ The article quoted Dr. Jerome Groopman, Chief of Experimental Medicine at Beth Israel Deaconess Medical Center in Boston, as saying: "An astounding 15\% of all patients who enter a hospital or doctor's office this year will be misdiagnosed, about half will face serious complications, even death."98 A year later, Parade magazine reported: "Prescription drug errors injure 1.5 million Americans every year and kill at least 7000 . Why? Because $95 \%$ of the 3 billion prescriptions issued annually are handwritten, leading to mistakes. So far, most physicians ... have not supported what many say is the solution: an electronic prescription system."

To demonstrate that customary medical practices are not always altered by knowledge of problems caused by that practice, I discuss the incidence of deliveries by Caesarean section. In the period of 1968 to 1977, the rate of births by Caesarean section tripled-from $5 \%$ of all deliveries to $15.2 \%{ }^{100}$ In 1984, Dr. Norbert Gleicher, Chair of the Department of Obstetrics and Gynecology at Mount Sinai Hospital

94. Michael Fumento, Editorial, The Threat of Hospital Infections, SAN DIEGO UNION-TriB., Aug. 7, 2004, at B8.

95. Lauran Neergaard, Doctors Ordered: Read the Drug Label, SAN DiEGo UNIONTRIB., Dec. 12, 2000, at A5.

96. Justin M. Norton, Statins Underprescribed for Many At-Risk Heart Patients, SAN DiEgo Union-TRIB., May 31, 2005, at A5.

97. The Most Dangerous Medical Mistake, PARADE, Apr. 1, 2007, at 16.

98. Id.

99. Rx for Medicine Mistakes, PARAdE, Jan. 20, 2008, at 10.

100. Doctor Says Caesareans Expose Women to Needless Risks, Expense, TRIBUNE (San Diego), Dec. 21, 1984, at A-40. 
Medical Center in Chicago and a professor at Rush Medical College, stated, "[I]n general the risk of maternal death is two to four times greater in the surgical procedure [than in vaginal delivery]." ${ }^{101}$ Despite repeated reports recommending that the use of the surgical procedure be limited to appropriate cases - due to the increased risk of harm both to the infant and to the mother - the rate of deliveries by Caesarean section increased to $22.6 \%$ in $1992^{102}$ and to $29 \%$ in $2003 .{ }^{103}$ A newspaper article published in 2007 reported: "U.S. women are dying from childbirth at the highest rate in decades, government figures show. Though the risk of death is very small, experts believe increasing maternal obesity and a jump in Caesarean sections are partly to blame.”104 Dr. Elliott Main, who co-chairs a panel that reviews obstetrics care in California, stated: "There's an inherent risk to C-sections .... A As you do thousands and thousands of them, there's going to be a price."105

Students have different emotional reactions to these articles. Some, especially those who have had favorable experiences with their doctors, may be surprised or even suspicious of the accuracy of the reports. Some may feel anxiety or even fear as they consider medical treatment for a condition they have or may have in the future. Others, especially those who have had unfavorable experiences with their doctors, may feel hostility toward or resentful of members of the medical profession. Whatever their emotional reaction, students are eager to engage in a discussion of whether the standard of care for physicians requiring conformity to the medical custom should be replaced by the reasonable physician standard or by some other standard.

\section{Negligence: Limitations on Duty To Act}

After considerable class time is devoted to discussing the reasonable person standard as the measure of care required to avoid a determination of negligence, we turn to situations in which a defendant avoids tort liability, not because he or she exercised reasonable care, but rather,

101. Id. A-8.

102. Caesarean Rate Called Excessive, SAN Diego Union-Trib., May 19, 1994, at 103. Mike Stobbe, Maternal Death Rate Is Highest in Years, SAN DiEgo UnIONTRIB., Aug. 25, 2007, at A3.

104. Id.

105. Id. 
because he or she was under no duty to exercise reasonable care. Students are always troubled by these cases because, as a general rule, the law requires people to act reasonably to avoid injuring others. However, in these special situations, for some policy reason, an innocent plaintiff cannot recover for his or her injuries despite the defendant's unreasonable behavior.

\section{The Failure To Rescue}

We begin our discussion with Hegel $v$. Langsam. ${ }^{106}$ In Hegel, parents of a seventeen-year-old, first-year undergraduate student sued the university she attended, claiming that the university allowed their daughter "to become associated with criminals, to be seduced, to become a drug user and further allowed her to be absent from her dormitory and failed to return her to her parents' custody on demand."107 The court held that the plaintiffs failed to state a cause of action, ruling that the university is under no "duty to regulate the private lives of [its] students, to control their comings and goings and to supervise their associations.",108 Students attending a university "must be presumed to have sufficient maturity to conduct their own personal affairs.",109

I ask the class whether the case was properly decided. Law students, most of whom have recently graduated from college, readily agree with the court's decision. The university should not interfere in the lives of its students even if parents believe their children have fallen into errant ways.

In our subsequent discussion, students learn the broader principle of the case - that one who has not created a new danger to the plaintiff is under no obligation to assist the plaintiff who is endangered from another source. I then challenge that principle by reading portions of a newspaper article entitled Bystanders Fail To Help Toddlers Floating in Pool. ${ }^{110}$

At least two bystanders failed to help two toddlers found floating face down in an apartment swimming pool, and a fire department official said he was baffled by their inaction.

"Anybody in their right mind-you'd think they would, but they didn't,” said Capt. C.A. Beasley.

106. 273 N.E.2d 351 (Ohio Ct. Com. Pl. 1971).

107. Id. at 352 .

108. Id.

109. Id.

110. Bystanders Fail To Help Toddlers Floating in Pool, EvEnING TriB. (San Diego), July 18, 1989 (on file with author). The fact situation occurred in Houston, Texas, and another version of the story appeared a day earlier in the Houston Chronicle. Toddler Drowns After Onlookers Do Nothing, Houston Chron., July 17, 1989, at A1. 
Beasley said two men stood by while Taffidie McGough, 2, and her 15-monthold half-sister, Tiffidie Anne, were [drowning] in the pool.

Tiffidie Anne was found floating face down in the shallow end of the pool and was declared dead at the scene.

Taffidie was on the bottom of the pool near her sister.... She remains in critical condition and on life-support systems at Texas Children's Hospital . . . .

District Attorney John B. Holmes said there are no criminal sanctions for failing to rescue the children.

"But common sense suggests that no caring, thinking human being would stand handily by while two kids were drowning," he said.111

I reiterate the statements of Captain Beasley and District Attorney Holmes. "Anybody in their right mind-you'd think they would [act to rescue those children], but they didn't.” “[C]ommon sense suggests that no caring, thinking human being would stand handily by while two kids were drowning." Tort law, I remind the students, is supposed to encourage people to engage in reasonable behavior. Is it reasonable to stand by and allow two young children to die without attempting to rescue them? Why do we have tort law if liability cannot be imposed in this situation?

The students are stunned, and they are stumped. The principle of law that they so readily adopted as compelling the result in the Hegel case seems to compel a result of no liability in the drowning toddlers case. In fact, Hegel may present an even stronger case for imposing liability than the drowning toddlers case. After all, there was some relationship between the parties in Hegel. The plaintiff's daughter was a student at the

111. Bystanders Fail To Help Toddlers Floating in Pool, supra note 110. The drowning toddlers situation is not unique. Consider, for example, this report of an incident occurring more than twenty years later:

The gang rape and beating of a 15-year-old girl on school grounds after her homecoming dance was horrific enough. But even more shocking, police said, was that up to two dozen people watched and did nothing to stop it.

$\ldots$

Two suspects were in custody yesterday, but police said as many as seven ranging in age from 15 to mid-20s beat and raped the girl for more than two hours at a dimly lit area near benches Saturday night. As many as two dozen people saw the rape without notifying police.

Officers found the girl semi-conscious and naked from the waist down near a picnic table. She remains hospitalized with non-life-threatening injuries.

"This was a barbaric act. I still cannot get my head around the fact that numerous people either watched, walked away or participated in her assault," Lt. Mark Gagan said yesterday. "It's one of the most disturbing crimes in my 15 years as a police officer."

Terry Collins, Town Rattled by Alleged Rape of Teen, SAn DiEgo UniOn-TRIB., Oct. 28, 2009, at A3. 
university. In the drowning toddlers example, there is no indication of any relationship between the children and the bystanders who did not come to their rescue. And yet, students are sympathetic to, and even compelled by, the idea that no caring, thinking human being-no reasonable person-would stand handily by while two kids were drowning. They feel contempt toward the two bystanders who failed to act.

I ask whether the legislature should change the common law rule by imposing a duty to rescue. ${ }^{112}$ I give them a specific example. I ask, "How many of you would support the enactment of legislation that declares a person to be guilty of criminal conduct if he or she either fails 'to render aid which is necessary and is clearly required immediately to a person in danger of death, if such aid could knowingly be rendered by the guilty person without serious danger to himself or to other persons, or [fails] to inform the appropriate [authorities] or persons of the necessity to render aid'?”

After the class considers the merits of the proposal and votes on whether it should be adopted, I inform them that the legislation I quoted was contained in the Criminal Code of the Russian Soviet Federative Socialist Republic. ${ }^{113}$ Ironically, we regard our society as being morally based, reflecting Judeo-Christian ethical precepts. And yet, Godless Communism appeared more willing to call upon its citizens to act as their brother's keepers. Each Soviet citizen was expected to take an interest in the welfare of his or her fellow citizens and to offer assistance to anyone who needed it.

I then offer a different perspective. Perhaps, it could be argued, that Soviet law was ever ready to resort to criminal legislation as an instrument of social engineering. In the United States, we are free to accept or reject our moral obligations - at least the moral obligation to assist a person in danger-without any fear of either criminal or civil liability.

112. For example, a Vermont statute imposes a duty on any person who knows that another is exposed to grave physical harm to give reasonable assistance to the exposed person to the extent that such assistance can be rendered without danger or peril to the rescuer. Willful violation of that statute, however, results in a maximum fine of only $\$ 100$. VT. STAT. AnN. tit. 12, § 519 (2009). The statute was enacted in 1967. Id.

113. Ugolovnyi Kodeks RSFSR [UK RSFSR] [RSFSR Criminal Code] art. 127 (Russ.), translated in The Criminal Code of the RSFSR, in THE SOVIET CODES OF LAW 53, 108 (William B. Simons ed., Harold J. Berman \& James W. Spindler trans., 1980). 


\section{The Failure To Rescue: Revisited}

About a week after our discussion of the Hegel case, I hold a special lunch and learn session for the class. ${ }^{114}$ I inform students that as we dine, they will see a video of a lawyer-client interview based on the facts of Hegel v. Langsam. I ask them to consider what issues they might expect to encounter if they were attorneys interviewing the plaintiff in that case and how they would handle those issues. In the video, I portray the father who wants to sue the university where his daughter attended. The lawyer in the interview is portrayed by a clinical law professor on our faculty.

I begin the interview by informing the lawyer that I am really upset. I am concerned about my daughter. In a matter of a couple of monthssince she started attending that university-her whole life has changed. She is drinking alcoholic beverages; she is taking drugs; she is running around with a guy who is seven years older than she is; she stays out all night and does not return to her dorm room. And the university is not doing anything to protect her, to guide her, to take care of her. They do not have any rules. When the lawyer asks me what I would like to achieve, I inform him that I would like to close down that den of iniquity, and that I would like to sue those bastards for every cent they have. The students see me as an emotionally distraught father, angrily blaming the university for my daughter's plight. Although the lawyer attempts to make me focus on specific issues-did the university agree to monitor my daughter's life; was there any language in their brochures that could be construed as an undertaking on their part; what was the specific date that I attempted unsuccessfully to visit my daughter-I continue my emotional harangue.

After the students see the video, the first question I ask is: "How would you like to be my daughter?” The students respond with a resounding "No way!" We then discuss the plight of the lawyer confronted by an extremely emotional client. Did the client's emotional outbursts make the attorney uncomfortable or ill at ease? Given the circumstances, did the attorney do a good job in trying to get the client to focus on

114. The University of San Diego has adopted an Enhanced Student-Faculty Interaction Initiative (ESFI) that provides funds to professors who wish to meet informally with their students on special occasions that have some educational merit. I provide pizza and drinks to the students who attend. Virtually all students in the class attend the session. 
factual information that might assist the attorney in evaluating legal issues that might be relevant to a potential claim? Would they have handled the interview any differently? Although the students do not personally experience the emotions that the client experiences, or the emotions that the attorney experiences in trying to interview the emotional client, nevertheless, for many students, this is the first time they have considered problems caused by emotions that they may well confront when they become members of the profession they are so eager to join. While they know the court in Hegel ruled that the plaintiff failed to state a cause of action against the university, how do they deal with an emotionally distraught client who is coming to see them, confident in the lawyer's ability to achieve success for them on a similar grievance?

We discuss what the lawyer was trying to achieve in the interview. For example, when the attorney informed me that he was confident that he would be able to compel the university to take a more active role in my daughter's life, was he simply trying to "sell" himself as competent to represent my interests? Would he regret making such a statement that I could construe as a promise, a promise that he might well be unable to keep? Could my disappointment in my attorney's inability to achieve this objective lead to a claim of malpractice by me against him?

We also consider the distinction between sympathy and empathy. ${ }^{115}$ In the context of the interview, sympathy suggests that the lawyer feels compassion toward, or pity for, the client because of the client's situation or problem. ${ }^{116}$ A lawyer who is sympathetic toward his or her client might propose a legal course of action that would enable the client to achieve a result that would lessen or eliminate the client's suffering. The lawyer is especially likely to seek a legal solution to the client's problem if the client also views his or her problem as a legal problem. In the example I presented, when I indicated that I wanted to close down the university and sue them for damages, the lawyer construed my problem as a legal problem by expressing confidence in his ability to make the university take a more active role in my daughter's life.

In contrast, empathy suggests that the lawyer understands the client's perspective. $^{117}$ An empathetic lawyer may be more willing to explore a

115. See Susan A. Bandes, Empathetic Judging and the Rule of Law, 2009 CARDOZO L. REV. DE NOVO 133, 136-37, http://www.cardozolawreview.com/content/denovo/BANDES _2009_133.pdf (discussing the distinction between sympathy and empathy).

116. Id. at 136 .

117. Id. Bandes asserts: "Cognitive empathy is perspective-taking. The rarer emotional empathy, a kind of emotional contagion, 'makes us experience others' suffering as our own." Id. at 136 n.15 (citing CANDACE ClARK, MiSERY AND COMPANY: SYMPATHY IN EVERYDAY LIFE 38 (1997)). 
nonlegal solution to a client's problem. In the example I presented, the lawyer may question whether suing the university, even if that suit is successful, will resolve the relationship problem that exists between my daughter and me. If a lawyer is able to build an empathetic connection with his or her client, the client may be more willing to accept the lawyer's advice that the lawyer believes will be helpful to the client-even if that advice does not result in using the lawyer's services to resolve the problem. When the lawyer interrupted my explanation of why I came to see him with questions that attempted to make me focus on specific issues relevant to a possible legal claim against the university, did he squander an opportunity to build an empathetic connection with his client by frustrating my desire to fully explain why I was so upset?

To complete our discussion, I suggest that an interview process, modeled after the three stages outlined by David Binder and Susan Price in their book Legal Interviewing and Counseling: A Client-Centered Approach, ${ }^{118}$ may provide guidance on how to conduct an improved interview. In the first stage-The Preliminary Problem Identificationthe client is provided with an opportunity to state, without interruption, the problem and the relief that the client seeks. In the second stageChronological Overview - the attorney goes back through the client's story asking open-ended questions in order to elicit data and fill in blanks. In the third stage-Theory Development and Verification-the lawyer explains to the client his or her understanding of the facts and issues involved and explores systematically the viability of legal theories suggested in the Overview stage. At this stage, the lawyer may also explore nonlegal options that may better assist the client to resolve the "real" problem.

The class then observes another video of the same interview, but one in which the attorney employs the interviewing technique mentioned above. For example, he begins by asking me to briefly discuss my problem and what I hope to achieve. Even though I become emotionally upset as I discuss my situation, he allows me to complete my remarks without interrupting me. Although in this interview, I try to be as disturbed as the client in the first interview, the technique of allowing me to complete my remarks without interruption enables me to focus on the attorney's questions as he engages in the fact-gathering necessary to

118. DAVid A. Binder \& SusAn C. Price, Legal InTERVIEWING AND COUNSELING: A Client-Centered APPROACH 53-103 (1977). 
deal with my problem. He has established a necessary rapport with me. When the lawyer suggests that we may not be successful in a lawsuit against the university unless we can establish some undertaking on their part to monitor or guide my daughter's life, I am more willing to accept that possibility than I was in the first interview. The attorney has at least listened to me-he is empathetic — and I am convinced he is trying to assist me in dealing with my difficult situation. Even when he suggests that part of my problem may be a relationship issue with my daughter that may benefit from professional counseling rather than a legal issue that he can help me solve, I am receptive to the suggestion. The two videos, and our class discussion, introduce students to issues they will study in far greater detail in an upper-class Interviewing and Counseling course. $^{119}$

\section{Attorney Duty of Confidentiality}

In discussing the standard of care applicable to lawyers, I ask whether attorneys who violate the ethical standards of their profession-the American Bar Association's Model Rules of Professional Conduct Codeshould be held liable in tort for an injury that results from such violation. The students readily accept that proposition. After all, they have learned that the customary standard of practice for professionals is equated with the reasonable person standard. ${ }^{120}$ If the profession itself imposes certain ethical standards of practice, then practitioners of that profession should be expected to conform to those standards.

I then present students with an ethical dilemma. Suppose the plaintiff is injured in an automobile accident and sues the defendant driver. As permitted under liberal discovery rules, you, as the defendant's lawyer, require the plaintiff to undergo a physical examination by a physician working for you in order to determine the extent of the plaintiff's injuries. The physician discovers a serious condition - an aorta aneurysm - that was probably caused by the accident. The plaintiff's own physician has not discovered this condition, and thus the plaintiff, and the plaintiff's attorney, are unaware of the condition. ${ }^{121}$ If left untreated, this aneurysm could

119. Just so the students do not leave the class with a mistaken impression of my relationship with my real daughter, I show a third video that displays the father-daughter dance that we performed at my daughter's wedding. To the song "Boney Maroney," we do a silly routine that we developed prior to the wedding. The audience at the wedding laughed. So do the students.

120. See supra text accompanying notes 90-91.

121. I tell students to assume that either this jurisdiction does not follow Federal Rule of Civil Procedure 35, which requires disclosure of the defendant's physician's report 
dilate further and rupture, resulting in the plaintiff's death. ${ }^{122}$ You request permission from your client to inform the plaintiff of the condition. The defendant refuses to grant permission because he or she does not want to be held liable for this additional injury. I inform the class that Rule 1.6 of the ABA Model Rules provides: "A lawyer shall not reveal information relating to the representation of a client unless the client gives informed consent...."123 In a comment to this rule, the ABA asserts: "A fundamental principle in the client-lawyer relationship is that, in the absence of the client's informed consent, the lawyer must not reveal information relating to the representation. ... This contributes to the trust that is the hallmark of the client-lawyer relationship."124 Should you, as the defendant's attorney, betray your client and violate your ethical obligation as an attorney in order to assist the plaintiff? If the answer is yes, should you be held liable to the defendant for any additional damages that are assessed against him or her?

The students are quite disturbed by this hypothetical. If they adhere to the ethical requirements of their profession and do not disclose the aneurysm, the plaintiff-admittedly an adversary, but a person nevertheless - may die. If they do disclose, they are breaching their ethical responsibility as attorneys and may be guilty of malpractice that would make them personally liable for any additional damages that can be assessed against their client. ${ }^{125}$ Some students try to find an easy way

upon the request of the plaintiff, or that if the jurisdiction does follow that rule, then the plaintiff has not made such request. See FED. R. Civ. P. 35.

122. The hypothetical is based on Spaulding v. Zimmerman, 116 N.W.2d 704 (Minn. 1962). In Spaulding, the Minnesota Supreme Court ruled that although "no canon of ethics or legal obligation may have required [the defendant or his lawyer] to inform plaintiff or his counsel with respect [to the aneurysm]," nevertheless, because the plaintiff was a minor, the trial court did not abuse its discretion in vacating the settlement agreed to between the parties. Id. at 710. In a subchapter entitled "Who Among Us Will Do the Right Thing?," the authors of a major casebook on professional responsibility reprint the Spaulding case and raise numerous questions about whether disclosure was "the right thing" to do in that case. GEOFFREY C. HAZARD, JR. ET AL., THE LAW AND ETHICS OF LAWYERING 313 (4th ed. 2005).

123. Model Rules OF Prof’l Conduct R. 1.6(a) (2009).

124. Id. cmt. 2.

125. In a study conducted twenty years ago, twelve hypothetical problems involving issues of whether the lawyer should disclose confidential information were submitted to lawyers and clients. One of the hypotheticals was based on the Spaulding case. Fred C. Zacharias, Rethinking Confidentiality, 74 IowA L. REV. 351, 409 hypo. 3, 409 n.280 (1989). Of the lawyers who responded, $67.3 \%$ said they would disclose the information about the aneurism to the plaintiff even if their client objected to the disclosure. Id. at 
out. They say that if their client refuses to allow the disclosure, they will cease representing their client and then disclose the condition to the plaintiff. However, I inform them that the ABA Model Rules impose certain duties on attorneys toward their former clients. Specifically, Rule 1.9(c) provides: "A lawyer who has formerly represented a client in a matter... shall not thereafter: (1) use information relating to the representation to the disadvantage of the former client ... or (2) reveal information relating to the representation . ..."126

The hypothetical forces students to consider whether there are higher ethical obligations - potentially saving a person's life - than the ethical obligations of one's profession - the duty of confidentiality to one's client. Indirectly, the discussion asks students to consider whether a rule of law-such as an ethical rule of one's profession, a broadly stated court decision, or a legislative enactment-which has been promulgated as a general standard applicable to most cases, should be adhered to in a new fact situation in which adherence may produce an unconsidered and undesirable result. Perhaps that concern explains why the ABA amended its Model Rule 1.6 in 2003 to allow a lawyer to "reveal information relating to the representation of a client to the extent the lawyer reasonably believes necessary ... to prevent reasonably certain death or substantial bodily harm.” ${ }^{127}$ Whether the facts of the hypothetical meet that standard for disclosure is uncertain.

\section{Negligently Inflicted Emotional Distress: Duty to Bystanders}

Traditionally, courts denied recovery to plaintiffs who suffered emotional distress from negligent conduct directed toward third persons. ${ }^{128}$ Because these bystander plaintiffs were outside the zone of physical danger, they were classified as unforeseeable plaintiffs and owed no duty under Justice Cardozo's reasoning in the landmark case of Palsgraf v. Long

\footnotetext{
392 tbl.III. Of the clients who responded, 91.2\% said the defendant's lawyer should disclose this information. Id. at 395 tbl.V. Of the twelve hypotheticals, the Spaulding hypothetical received the second highest percentage of prodisclosure responses from attorneys and the highest percentage of prodisclosure responses from clients. Id. at 392 tbl.III, 395 tbl.V. The results of this study suggest that attorney disclosure in the Spaulding case conforms to the customary standard of practice of attorneys and is therefore not a breach of duty. The results also suggest that if the issue is submitted to a jury in a lawsuit brought by the Spaulding defendant against his or her attorney for the additional damages imposed against the defendant, the jury is unlikely to impose tort liability on the attorney who made the disclosure.

126. MODEL Rules OF PROF’L CONDUCT R. 1.9(c).

127. Id. R. 1.6(b)(1).

128. Dan B. DobBs, The LaW Of TorTs 839 (2000).
} 
Island Railroad Co. ${ }^{129}$ I begin my discussion of this unit by asking whether a duty can be found when the plaintiff suffers emotional distress caused by the defendant's negligence that endangers a third person. For example, if the defendant endangers the life of a child, is it reasonably foreseeable that the child's mother will suffer emotional distress? In Wagner v. International Railway Co., ${ }^{130}$ Cardozo found a duty to a rescuer of a negligently injured third person. If Cardozo can find a duty to the rescuer, I can find a duty to the child's mother in my hypothetical. I then paraphrase Cardozo. Instead of "Danger invites rescue. The cry of distress is the summons to relief.... The wrong that imperils life is a wrong to the imperiled victim; it is a wrong also to his rescuer," ${ }^{\text {"131 I }}$ suggest "Danger invites the concern of others. The cry of distress is the summons to mental disturbance of concerned loved ones.... The wrong that imperils life is a wrong to the imperiled victim; it is a wrong also to his mother." If the students find my choice of words amusing, I note that in the very next sentence of the Wagner case, Cardozo states that when a child is in danger, the child's parent is its foreseeable rescuer. ${ }^{132}$

In 1968, the California Supreme Court broke from tradition by ruling that a mother who claimed that she had witnessed the death of her child as a result of the defendant's negligent driving of an automobile stated a cause of action for the emotional injuries that she had suffered even though she was not within the zone of physical danger. ${ }^{133}$ As the court stated in Dillon $v$. Legg: "The concept of the zone of danger cannot properly be restricted to the area of those exposed to physical injury; it must encompass the area of those exposed to emotional injury." "134 If harm to the plaintiff is reasonably foreseeable-whether that harm is physical injury or emotional distress-defendant is under a duty of

129. 162 N.E. 99, 99-101 (N.Y. 1928).

130. 133 N.E. 437, 437-38 (N.Y. 1921).

131. Id. at 437.

132. Citing Gibney v. State, 33 N.E. 142 (N.Y. 1893), Cardozo writes, "The state that leaves an opening in a bridge is liable to the child that falls into the stream, but liable also to the parent who plunges to its aid.” Wagner, 133 N.E. at 437-38.

133. Dillon v. Legg, 441 P.2d 912, 921 (Cal. 1968).

134. Id. at 920 n.5. The court added: "[I]n awarding recovery for emotional shock upon witnessing another's injury or death, we cannot draw a line between the plaintiff who is in the zone of danger of physical impact and the plaintiff who is in the zone of danger of emotional impact." Id. 
reasonable care to avoid causing such injury. ${ }^{135}$ The court identified three factors that serve as guidelines to assist courts in determining whether emotional distress to plaintiff was reasonably foreseeable. ${ }^{136}$ Over the years, most states have followed the California Supreme Court's lead in replacing the zone of physical danger limitation with a rule that permits recovery for emotional distress damages in at least some bystander cases. ${ }^{137}$

In Thing v. La Chusa, ${ }^{138}$ decided twenty-one years after Dillon, the California Supreme Court expressed concern that although the Dillon court had expected future cases to define the parameters of bystander recovery, subsequent decisions of the California Supreme Court and California Courts of Appeal had expanded liability by relaxing the Dillon guidelines. ${ }^{139}$ Those decisions failed to consider "the importance of avoiding the limitless exposure to liability that the pure foreseeability test of 'duty' would create and towards which these decisions have moved." 140 Thus the Thing court ruled that for bystander plaintiffs, "foreseeability of injury alone does not justify imposition of liability for negligently caused emotional distress." 141 The court reformulated and narrowed the Dillon guidelines, and imposed them as requirements. The Thing court concluded that a bystander plaintiff

may recover damages for emotional distress caused by observing the negligently inflicted injury of a third person if, but only if, said plaintiff: (1) is closely related to the injury victim; (2) is present at the scene of the injury producing event at the time it occurs and is then aware that it is causing injury to the victim; and (3) as a result suffers serious emotional distress-a reaction beyond

135. Id. at 920-21.

136. The factors are: (1) whether the plaintiff was located near the scene of the accident, (2) whether the plaintiff contemporaneously observed the accident, and (3) whether the plaintiff and the victim were closely related. Id. at 920.

137. See DoBBS, supra note 128 , at 840 \& n.11 (citing cases decided by the highest appellate courts in fifteen states that follow the Dillon precedent); but see EDWARD J. KIONKA, TORTS IN A NUTSHELL 331 (4th ed. 2005) (asserting that "most courts continue to deny recovery" to bystander plaintiffs). Kionka acknowledges, however, that the rule of nonliability to bystander plaintiffs "has been rejected in exceptionally compelling cases"-citing Dillon as the leading decision and noting that "Dillon has been followed in several jurisdictions in cases involving similar facts, but it has been expressly rejected in several others (e.g., Tobin v. Grossman, N.Y. 1969).” KIONKA, supra, at 332 (citing Tobin v. Grossman, 249 N.E.2d 419 (N.Y. 1969)).

138. 771 P.2d 814 (Cal. 1989).

139. Id. at 821. See id. at 821-27 (discussing cases that expanded liability by relaxing the Dillon guidelines).

140. Id. at 821.

141. Id. at 827 (citing Elden v. Sheldon, 758 P.2d 582 (Cal. 1988)). 
that which would be anticipated in a disinterested witness and which is not an abnormal response to the circumstances. ${ }^{142}$

Thus, in the Thing case, the mother of a child who was injured when struck by a negligently driven automobile was not permitted to recover for the emotional distress she suffered when she arrived at the accident scene shortly after the accident occurred and discovered her bloody and unconscious child lying in the roadway. ${ }^{143}$ The mother failed to satisfy the rigid second requirement announced in Thing.

I ask the class to consider whether the child's mother was a foreseeable plaintiff. Even though she did not witness the accident, she was in the vicinity and arrived on the scene while her child, who she thought was dead when she first saw him, was lying unconscious and bleeding in the roadway. ${ }^{144}$ Would a reasonable person in the defendant's position foresee that if he or she drove negligently and seriously injured a child, that the child's mother, upon discovering her child shortly after the accident, would suffer serious emotional distress? The obvious answer is "yes." Should this mother's claim be denied simply because she fails to satisfy an arbitrary requirement that she be present at the scene of the injuryproducing event at the time it occurs and be aware at the time that it is causing injury to her child? Do we really believe that this mother's claim of emotional distress is less likely to be genuine than the claim of a mother who happened to see or hear the accident when it occurred? Shouldn't the plaintiff be permitted to offer evidence to a jury to prove that she really did suffer serious emotional distress?

The students have a strong emotional reaction to the facts of the Thing case - the child's mother discovers her bloody, unconscious child in the road and believes him to be dead-and they support her quest for recovery. One could well assert that the students' reaction is similar to the reaction of appellate court judges to other compelling fact situations that arose after the Dillon decision. Such a reaction may have led those courts to expand bystander recovery by relaxing the Dillon guidelines. ${ }^{145}$

142. Thing, 771 P.2d at 829-30 (footnotes omitted).

143. Id. at 815 .

144. Id.

145. The first Thing requirement that the bystander "be closely related to the injury victim" may also be challenged as unduly arbitrary. In a footnote, the Thing court explains that requirement by stating: "Absent exceptional circumstances, recovery should be limited to relatives residing in the same household, or parents, siblings, children, and grandparents of the victim.” Id. at 829 n.10. Under this rule, while grandparents can recover for a negligent 
I ask the class to consider whether their desire to grant recovery to Maria Thing is based solely on a desire to treat her equally with Margery Dillon. The broader question to be asked is whether they both should be granted a remedy for the emotional distress they had suffered or whether they both should be denied recovery. If the rigid Thing requirements are objectionable, should courts (1) return to the traditional rule of denying recovery to both plaintiffs because they were outside the zone of physical danger, (2) return to the Dillon approach of amorphous guidelines, or (3) use a pure foreseeability approach that would probably allow recovery to both mothers? ${ }^{146}$

We engage in a discussion of the reasons why courts have historically denied recovery to bystander plaintiffs- "the twin fears that courts will be flooded with an onslaught of (1) fraudulent and (2) indefinable claims." ${ }^{\text {"147 }}$ The Dillon court carefully considered those reasons and, with the adoption of suggested guidelines to determine foreseeability, rejected them. ${ }^{148}$ I remind the class that the oldest case in the Prosser torts casebook is I de $S$ et ux. v. W de $S,{ }^{149}$ decided in 1348-more than 660

injury to their grandchildren, grandchildren can only recover for a negligent injury to their grandparents if they reside in the same household.

146. In challenging the Thing requirements, I also discuss Holliday v. Jones, 264 Cal. Rptr. 448 (Ct. App. 1989). In that case, Mr. Holliday was convicted of involuntary manslaughter for killing his wife. Eventually the conviction was reversed because Mr. Holliday's defense counsel was incompetent. Represented by a different lawyer on retrial, Mr. Holliday was acquitted. He sued his first attorney for legal malpractice and obtained a judgment of $\$ 1,100,000$, which included $\$ 150,000$ for the emotional distress suffered by his two minor children. Id. at 449 . In focusing on the question of whether the children should be permitted to recover for the emotional distress they had suffered, the California Court of Appeal began its analysis by stating: "Initially we wish to emphasize the evidence in this case clearly establishes [that the lawyer's] negligence caused the Holliday children to suffer emotional distress.” Id. at 450. The court then described in detail that distress, including these statements: "The children worried about how long they would be separated from their father and how and where they would live during this period. They resided at seven different locations during their father's incarceration. Their schoolmates asked them embarrassing questions and their schoolwork suffered dramatically." Id. The court concluded its analysis of this portion of the case by acknowledging: "The Holliday children are indeed sympathetic victims who have suffered as a foreseeable result of [their father's lawyer's] negligence.” Id. Nevertheless, relying upon the Thing requirements for bystander recovery, the court held that "the Holliday children are not entitled to recover damages for the negligently inflicted emotional distress caused by [their father's lawyer's] conduct.” Id. at 453. I ask whether recovery should be denied to plaintiffs who the appellate court acknowledges are sympathetic victims that the evidence clearly establishes have suffered serious emotional distress as a foreseeable result of the defendant's negligence?

147. Dillon v. Legg, 441 P.2d 912, 917 (Cal. 1968).

148. Id. at 917-25.

149. Y.B. Lib. Ass. fol. 99, placitum 60 (at the Assizes 1348), reprinted in SCHWARTZ ET AL., supra note 54 , at 37. 
years ago. In $I$ de $S$, the court ruled that emotional distress alone, even without any accompanying physical injury, is itself an injury for which the law, through the tort of assault, will grant recovery to a plaintiff. ${ }^{150}$ Today we know far more about this type of injury than was known in 1348. Should we deny recovery today for genuine claims of emotional distress because of our concern that a plaintiff's injury cannot be precisely defined or might be fraudulently asserted? For hundreds of years, we have relied upon lawyers to present evidence to support and refute claims of emotional distress and on jurors to weigh that evidence and make appropriate decisions as to liability. Even for purely physical injuries, jurors are routinely called upon to determine appropriate monetary awards for the pain and suffering of tort victims. Pain and suffering are experienced through the mind of the victim. If jurors are competent to determine the monetary worth of pain and suffering, why should jurors be considered any less competent to determine emotional distress damages?

In Thing, the California Supreme Court raised another policy consideration to justify limiting liability to bystander plaintiffs. The court asserted that the desirability of avoiding "limitless liability out of all proportion to the degree of a defendant's negligence, and against which it is impossible to insure without imposing unacceptable costs on those among whom the risk is spread" justifies "restrictions on recovery for emotional distress notwithstanding the sometime arbitrary result." ${ }^{151}$ I ask the class to consider whether the inability of a defendant to insure against the cost of an injury wrongfully inflicted on a plaintiff justifies an admittedly arbitrary decision to deny tort recovery to that victim. After all, if the defendant had not engaged in the unreasonable behavior in the first place, the plaintiff would not have been injured. Typically, the class rejects the Thing court's reasoning, even though the result may mean that innocent policy owners may be charged higher premiums on their insurance policies.

Finally, I ask whether the costs of bystander plaintiff recovery and the possibility of fraudulent claims warrant at least some modification in the way in which claims are processed, even if the Thing rules-considered as a package of three requirements-are too restrictive. If, for example, courts employ a foreseeability approach, should the bystander plaintiff be required to prove damages by a higher standard than is usually employed?

150. See id.

151. Thing, 771 P.2d at 826-27. 
Instead of requiring proof of injury by a preponderance of the evidence, would students support a rule that requires proof by clear and convincing evidence, or even proof beyond a reasonable doubt?

I also ask whether courts should focus on the injury requirement to appropriately limit a defendant's potential liability. In the Thing case, the California Supreme Court required bystanders to prove that they had suffered serious emotional distress and further defined such distress as "a reaction beyond that which would be anticipated in a disinterested witness and which is not an abnormal response to the circumstances." ${ }^{\prime 152}$ That Thing requirement was not a revision of a Dillon guideline, but rather, was a new requirement that parallels the Restatement of Torts requirement that the plaintiff suffer severe emotional distress in order to recover for the tort of intentional infliction of emotional distress. ${ }^{153}$ Negligence is a lower level of fault than intentional misconduct. Therefore, if a plaintiff is required to prove that he or she suffered severe emotional distress to recover for the intentional tort, then requiring a plaintiff to prove that he or she suffered serious emotional distress should not be objectionable for negligently inflicted emotional distress.

The students' emotional reaction to the Thing facts surely influences their judgment about the undesirability of adopting arbitrary requirements to limit bystander recovery. Nevertheless, I believe it is important to temper their emotional response with a rational discussion of reasonable restrictions that could be placed on bystander recovery that would reassure courts that defendants are not exposed to excessive liability.

\section{E. Punitive Damages}

In State Farm Mutual Automobile Insurance Co. v. Campbell, ${ }^{154}$ the United States Supreme Court held that a punitive damage award of \$145 million in a case in which compensatory damages were only $\$ 1$ million was excessive and violated the Due Process Clause of the Fourteenth Amendment. ${ }^{155}$ Although the Court declined to impose a bright-line

152. Id. at 830 (citing and quoting from Rodrigues v. State, 472 P.2d 509 (Haw. 1970)). In Rodrigues, the Hawaii Supreme Court ruled: “[S]erious mental distress may be found where a reasonable [person] normally constituted, would be unable to adequately cope with the mental distress engendered by the circumstances of the case.” Rodrigues, 472 P.2d at 519.

153. Comment j to section 46 of the Restatement (Second) of Torts limits recovery for the tort of intentional infliction of emotional distress to situations in which the emotional "distress inflicted is so severe that no reasonable person could be expected to endure it." RESTATEMENT (SECOND) OF TORTS § 46, cmt. j (1965).

154. 538 U.S. 408 (2003).

155. Id. at $412,429$. 
ratio that a punitive damage award cannot exceed, ${ }^{156}$ Justice Kennedy, writing for the Court's majority, declared: “[I]n practice, few awards exceeding a single-digit ratio between punitive and compensatory damages, to a significant degree, will satisfy due process."157

I ask the class whether they agree with the Supreme Court's decision to impose a single-digit ratio limitation on punitive damages. I note that the lawsuit before the Court involved the tort of insurance bad faith. The case did not involve a defendant who intentionally inflicted either a physical injury or death on a person, but rather, only an economic injury. The jury found that the insurance company refused to pay a claim against their insured in good faith. Although Justice Kennedy acknowledged "that State Farm's handling of the claims against the Campbells merits no praise," is conduct that inflicts only economic loss and not physical injury or death sufficiently reprehensible ${ }^{158}$ to warrant the award of punitive damages in addition to compensatory damages? Even if some award of punitive damages is appropriate, is a single-digit ratio limitation on punitive damages appropriate to prevent excess punishment of a defendant in a civil lawsuit?

As a part of our discussion, I ask the class to consider what possible argument could have been made by the plaintiff's attorney that would convince the jury in the Campbell case to make a punitive damage award of \$145 million when compensatory damages were only \$1 million. As they are contemplating that question, I read a portion of Justice Ginsberg's dissent in the case-a dissent that was not reproduced in the casebook:

The trial court ... determined that the jury could find State Farm's policy "deliberately crafted" to prey on consumers who would be unlikely to defend themselves. In this regard, the trial court noted the testimony of several former State Farm employees affirming that they were trained to target "the weakest of the herd" - "the elderly, the poor, and other consumers who are least knowledgeable about their rights and thus most vulnerable to trickery or deceit,

156. Id. at 425

157. Id.

158. I specifically chose the word "reprehensible" in my question to the students. In BMW of North America, Inc. v. Gore, 517 U.S. 559, 575 (1996), the Supreme Court articulated three guidelines for courts to use in reviewing the reasonableness of punitive damage awards. The first and "most important indicium of the reasonableness of a punitive damages award is the degree of reprehensibility of the defendant's conduct.” In Campbell, the Court repeated its assertion that the reprehensibility of the defendant's conduct is "the most important indicium of a punitive damages award's reasonableness." Campbell, 538 U.S. at 409. 
or who have little money and hence have no real alternative but to accept an inadequate offer to settle a claim at much less than fair value."

The Campbells themselves could be placed within the "weakest of the herd" category. The couple appeared economically vulnerable and emotionally fragile. At the time of State Farm's wrongful conduct, "Mr. Campbell had residuary effects from a stroke and Parkinson's disease.”

To further insulate itself from liability, trial evidence indicated, State Farm made "systematic" efforts to destroy internal company documents that might reveal its scheme, efforts that directly affected the Campbells. For example, State Farm had "a special historical department that contained a copy of all past manuals on claim-handling practices and the dates on which each section of each manual was changed." Yet in discovery proceedings, State Farm failed to produce any claimhandling practice manuals for the years relevant to the Campbells' bad-faith case. ${ }^{159}$

The students are outraged. How could the Court's majority simply characterize the defendant's handling of the claim against the Campbells as "merit[ing] no praise"? People purchase an insurance policy in order to have peace of mind when a problem arises that is covered by that policy. When a claim against an insured arises, the insured expects that the insurance company will pay that claim in good faith. State Farm's conduct in the Campbell case was egregious. It was sufficiently detestable that an award of punitive damages in a significant amount was appropriate.

But how do we go about determining what is an appropriate amount? In reaching its judgment that the jury's punitive damage award in Campbell was excessive, the majority noted that the harm suffered by plaintiffs "arose from a transaction in the economic realm, not from some physical assault or trauma; there were no physical injuries." ${ }^{160}$ Further, the majority asserted that much of the award of compensatory damages was for the emotional damages caused by the outrage and humiliation that the Campbells had suffered because of the actions of their insurer. Thus, the compensatory damages "were based on a component which was duplicated in the punitive award."

I ask students whether they find the majority's reasoning persuasive. Most students find State Farm's conduct so repugnant that they are not persuaded. We then discuss arguments that could be made to support a larger award of punitive damages. For example, was it appropriate for the Court to characterize emotional distress damages as both compensatory and punitive? If so, then could the award of any noneconomic damage — such as pain and suffering —also be construed as punitive? Courts have not so construed them. Consider also that the award of punitive damages as punishment differs from other punishment that can

159. Campbell, 538 U.S. at 433-34 (Ginsberg, J., dissenting).

160. Id. at 426 (majority opinion).

161. Id. 
be imposed in a criminal case. No one is being locked up, losing his or her liberty. All that is happening in this case is that a large corporation is being required to pay money for the wrongdoing of its employees. If the award of punitive damages is supposed to discourage abhorrent behavior by the defendant, will a formula that limits the maximum punitive damage award to a single-digit multiplier of compensatory damages assure society that the defendant will be adequately discouraged from repeating the conduct? Will some defendants-especially large corporations - be able to calculate possible punitive damage awards as an acceptable cost of doing business, thus defeating the very purpose of awarding punitive damages? For example, in what has been denounced as "[t]he most infamous tort case," "162 a woman received a \$2.9 million jury verdict, of which $\$ 2.7$ million was for punitive damages, after she burned herself while trying to remove the cover of a cup of hot coffee purchased at McDonald's. ${ }^{163}$ While most people know of that case and condemn the jury's decision, few are aware of evidence, presented at trial, that supported the jury's decision. At the time, McDonald's required its franchises to brew its coffee at 195 to 205 degrees and to serve it to customers at 180 to 190 degrees. ${ }^{164}$ By comparison, coffee made at home is brewed at 130 to 140 degrees. ${ }^{165}$ The plaintiff, Stella Liebeck, was a seventy-nine-year-old woman at the time of the incident who suffered third-degree burns to her groin, inner thighs and buttocks. She was hospitalized for seven days for a series of painful skin grafts. ${ }^{166}$ At trial, McDonald's asserted that the plaintiff contributed to her injury by not removing her clothing immediately after the coffee spilled. However, an expert for the plaintiff testified that it takes less than three seconds to produce a third-degree burn at 190 degrees, but about twenty seconds if the coffee had been 160 degrees. ${ }^{167}$

Additionally, in the ten-year period prior to this event, "McDonald's had received at least 700 reports of coffee burns ranging from mild to

162. CARL T. Bogus, Why LaWsuits Are GoOd FOR AMERICA 19 (2001).

163. Liebeck v. McDonald's Rests., P.T.S., Inc. No. CV-93-02419, 1995 WL 360309 (N.M. Dist. Ct. Aug. 18, 1994), vacated, No. CV-93-02419, 1994 WL 16777704 (N.M. Dist. Ct. Nov. 28, 1994) (unpublished order).

164. Andrea Gerlin, A Matter of Degree: How a Jury Decided that a Coffee Spill Is Worth \$2.9 Million, WALL ST. J., Sept. 1, 1994, at A1.

165. Bogus, supra note 162, at 19.

166. Gerlin, supra note 164.

167. Id. 
third degree, and had settled claims arising from scalding injuries for more than \$500,000." ${ }^{\prime 68}$ Apparently, McDonald's had made an economic judgment that the potential cost of lawsuits for injuries caused by their superheated coffee did not outweigh the benefit of the profits that could be made by continuing to serve superheated coffee to customers. I inform the students that McDonald's sells a billion cups of coffee a year, ${ }^{169}$ and that the $\$ 2.7$ million that the jury awarded as punitive damages in this case was an amount equal to two days of McDonald's coffee sales. Having provided those additional facts, I ask students whether, in their judgment, the award was excessive. Most agree that the award was not excessive. ${ }^{170}$

\section{F. Products Liability: Defining Defect}

In 1965, the American Law Institute published its final draft of section 402A of the Second Restatement of Torts. That landmark section declares that strict liability is imposed for physical harm caused to the ultimate user or consumer of a product that is sold "in a defective condition unreasonably dangerous to the user or consumer." 171 Comment $\mathrm{i}$ to section 402A clarified the meaning of the words "unreasonably dangerous.” A product is not unreasonably dangerous-and therefore is not defective-simply because it cannot be made entirely safe for all consumption. Sugar, for example, may be a deadly poison to diabetics but is not an unreasonably dangerous product. Whiskey is not unreasonably dangerous merely because it makes some people drunk and is especially dangerous to alcoholics. Butter is not unreasonably dangerous simply because it deposits cholesterol in the arteries and leads to heart attacks. ${ }^{172}$

In discussing section 402A's definition of “defect," I challenge the limitations on strict liability suggested by comment i. I ask the class to consider two products - each of which generates strong emotional

168. Id.

169. Id.

170. In the case, the jury found that the plaintiff was contributorily negligent and assessed her fault at 20\%. Thus the plaintiff's compensatory award was reduced to $\$ 160,000$. Liebeck v. McDonald's Rests., P.T.S., Inc., No. CV-93-02419, 1995 WL 360309 (N.M. Dist. Ct. Aug. 18, 1994), vacated, No. CV-93-02419, 1994 WL 16777704 (N.M. Dist. Ct. Nov. 28, 1994) (unpublished order). On the defendant's motion, the trial judge reduced the jury's punitive damage award to $\$ 480,000$. Liebeck v. McDonald's Rests., P.T.S., Inc., No. CV-93-02419, 1994 WL 16777706 (N.M. Dist. Ct. Nov. 28, 1994) (order on defendant's post-trial motion). Although McDonald's appealed, the parties ultimately settled for an undisclosed sum. Liebeck, 1994 WL 16777704 (order on motion to vacate).

171. RESTATEMENT (SECOND) OF TORTS § 402A (1965).

172. Id. cmt. i. 
reactions. The first is a Monster Thickburger ${ }^{\circledR}$ — which can be purchased at Hardee's fast food restaurant-a burger containing 1320 calories, 95 grams of fat (including 36 grams of saturated fat), 210 milligrams of cholesterol, and 3020 milligrams of sodium. ${ }^{173}$ When this burger was first marketed in November 2004, Hardee's hailed it as "a monument to decadence." ${ }^{174}$ The executive director of the Center for Science in the Public Interest declared the Monster Thickburger ${ }^{\circledR}$ to be "a heart attack on a bun." 175 Because the dangers of this product are well knownincreased risk of coronary heart disease, type 2 diabetes, and various cancers - does this mean that it is not a defective product? Should fast food makers be immunized from liability when they produce and sell such products because they are characterized as not unreasonably dangerous? ${ }^{176}$

The students are split on this issue. Some strongly believe that liability is completely inappropriate here. People know that these burgers are high in calories and fat, but they should have the option of eating one if they choose to do so. After all, this is supposedly a free country, and we should be able to make decisions that impact our own lives without anyone's interference- - even if others view our decisions as unwise or even harmful to ourselves. Do we really want to return to a time of Prohibition, when people were not permitted to drink alcoholic beverages? What is next, prohibiting smoking or overeating - or even drinking coffee that others view as too hot for our own good? Imposing tort liability on producers of various products that are declared to be defective results in those products being taken off the market, diminishing our freedom of choice. Let the market decide whether the

173. Hardee's, Hardee’s Menu, http://www.hardees.com/menu/ (last visited Apr. 5, 2010) (nutrition information for $2 / 3$ lb. Monster Thickburger ${ }^{\circledR}$ ).

174. Kevin Tibbles, Hardee's Unveils the Biggest Burger Ever, MSNBC, Nov. 16, 2004, http://www.msnbc.msn.com/id/6505575/.

175. Id.

176. Hardee's is not alone in selling burgers that are high in calories and fat. Ruby Tuesday's, for example, created an Ultimate Colossal Burger that outdoes Hardee's Monster Thickburger $^{\circledR}$. The Ultimate Colossal Burger contains 1677 calories, including 1026 calories from fat. The total grams of fat in this burger is 114.0, which is $175 \%$ of the fat that an adult on a 2000-calorie diet should ingest in a day. Calories in Ruby Tuesday Colossal Burger, http://caloriecount.about.com/calories-ruby-tuesday-colossalburger-i54870 (last visited Apr. 5, 2010). MSNBC reported an even higher calorie and fat count for the Ultimate Colossal Burger: 1940 calories and 141 grams of fat. Allison Linn, On Some Menus, One Plate Packs 2,000 Calories, MSNBC, Mar. 5, 2007, http://today.msnbc.msn.com/ id/17349197/. 
product should be sold, ${ }^{177}$ not some overweight consumer who, having chosen to eat a Monster Thickburger ${ }^{\circledR}$ —or many of them—now seeks to blame the restaurant for his or her excessive bulk and deny others the choice that he or she had to consume a burger.

Other students are equally appalled that Monster Thickburgers ${ }^{\circledR}$ and other such products are served today. Obesity is a national epidemic. Between 1980 and 2004, the prevalence of obesity in the United States doubled among adults. ${ }^{178}$ The National Centers for Disease Control and Prevention reports that more than one-third of American adults-over 72 million people-are obese. ${ }^{179}$ Obesity, and the health problems associated with obesity, is no laughing matter. Why should Hardee's be able to poison a person with its "monument to decadence" simply because that individual was willing to pay $\$ 5.49$ to receive it? If a father or a mother dies from a heart attack, or contracts cancer or diabetes, caused in part by ingestion of those burgers, the whole family—not just the individual-is adversely impacted. Consider also the marketing practices of fast food restaurants. Who do they target as their victims? It is not just adults who seek a quickly prepared meal. It is also children and teenagers who are the objective of their marketing practices. ${ }^{180}$ If parents are unwilling or unable to protect their children from the dangers of these products, shouldn't the tort system be available to do that job?

The second product I discuss is a .50 caliber rifle, which was described on a CBS 60 Minutes news segment as

\footnotetext{
the Rolls Royce of sniper rifles. It's a big gun, a favorite of armies around the world, and it's still available in 49 states in this country to anyone over 18 with a clean record.

It is, without a doubt, the most powerful weapon you can buy.... [I]t's powerful enough to kill a man or pierce armor from more than a mile away.
}

177. Why do you suppose McDonald's was able to sell one billion cups of superheated coffee a year? That is the way customers wanted their coffee served. Why do you suppose the Liebeck case was widely condemned in the popular press? Because McDonald's customers wanted to continue to have their coffee served superhot.

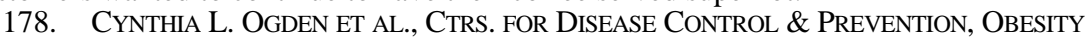
AmONG Adults in the United States-No Statistically Significant Change SinCE 2003-2004, at 1-2 (2007), http://www.cdc.gov/nchs/data/databriefs/db01.pdf.

179. Id. The National Centers for Disease Control and Prevention also reports that two-thirds - yes, two-thirds - of American adults are overweight or obese. See Centers for Disease Control and Prevention, Obesity and Overweight: FastStats, http://www. cdc.gov/nchs/fastats/overwt.htm (last visited Apr. 5, 2010).

180. See Michael S. Rosenwald, McDonald's Tries To Get Moms on Its Side, SAN Diego Union-TriB., Nov. 28, 2008, at A20 (describing McDonald's program to improve its image by recruiting mothers as Quality Correspondents to convince customers of the nutritional value of its products). 
A Senate report said that a bullet from a .50-caliber rifle, even at 1.5 miles, crashes into a target with more energy than a bullet fired at point-blank range from Dirty Harry's famous .44 Magnum. ${ }^{181}$

Although the .50 caliber rifle is a military-grade weapon and is used by the armed forces of thirty-five countries, it is also available to private citizens for target shooting and big game hunting. ${ }^{182}$ Is the .50 caliber rifle a defective product because of the danger it poses to a potential victim located a mile-and-a-half away from the person firing the rifle? ${ }^{183}$ Is the .50 caliber rifle a defective product because it could be purchased and used by a terrorist?

Again, the class divides on this issue. Some, citing the Second Amendment and our constitutional right to bear arms, believe that legitimate use of this rifle should not be precluded. After all, the real problem is not the rifle itself, but rather, misuse of the rifle by the person firing the rifle. If tort liability is to be imposed, it should be imposed on the user who causes the injury, not on the manufacturer or seller of the rifle. The product is not defective simply because it is powerful and can strike a target a mile-and-a-half away.

Others question whether a rifle this powerful should be available to civilians. Isn't the danger that it could be purchased and used by a terrorist so great that prohibition of sale to civilians is justified? Does the enjoyment of target shooting and killing big game by users of the product - the benefit of the product-really outweigh the danger inherent in the weapon itself if it should fall into the wrong person's

181. Rebecca Leung, Big Rifle a Terrorist Tool?, CBS NEWS, Jan. 9, 2005, http://www.cbsnews.com/stories/2005/01/06/60minutes/main665257.shtml. In 2004, California enacted legislation that banned the sale of .50 caliber rifles to civilians. .50 Caliber BMG Regulation Act of 2004, ch. 494, 2004 Cal. Stat. 91 (codified as amended in scattered sections of Cal. Penal Code (2005)). See People v. James, 94 Cal. Rptr. 3d 576, 577 (Ct. App. 2009) (holding that possession of an assault weapon in California-including a .50 caliber rifle-is not protected by the Second Amendment as construed by the United States Supreme Court in District of Columbia v. Heller, 128 S. Ct. 2783 (2008)). The James court cited numerous examples discussed by the California Supreme Court in Kasler v. Lockyer, 2 P.3d 581, 586-89 (Cal. 2000), describing why such rifles are unusually dangerous weapons. James, 94 Cal. Rptr. 3d at 581-82.

182. Leung, supra note 181.

183. Although section 402A specifically imposes strict liability on sellers of defective products that cause injury to users or consumers of the product, comment o to section 402A declares that " $[\mathrm{t}]$ here may be no essential reason why [non-users and nonconsumers] should not be brought within the scope of the protection afforded .... . The Institute expresses neither approval nor disapproval of expansion of the rule to permit recovery by such persons.” RESTATEMENT (SECOND) OF TORTS § 402A cmt. o (1965). 
hands - the risk of the product? If our constitutional right to bear arms permits us to possess a .50 caliber rifle, does it also permit us to possess hand grenades, or even weapons of mass destruction?

The use of the Monster Thickburger ${ }^{\circledR}$ and the .50 caliber rifle examples set the stage for a discussion of the changes to the product liability provisions contained in the Third Restatement of Torts, published in 1998, thirty-three years after the Second Restatement of Torts was published. The most fundamental change was to abandon a single definition for all product defects and to replace it with separate definitions for manufacturing defects, defects in design, and defects in warnings. ${ }^{184}$ A product is defective in design "when the foreseeable risks of harm posed by the product could have been reduced or avoided by the adoption of a reasonable alternative design ... and the omission of the alternative design renders the product not reasonably safe." 185 The Third Restatement reporters acknowledge that in assessing whether a product's design is defective, "the viewpoint of a reasonable person" is used to compare the product's design with an alternative design. ${ }^{186}$ In essence, the Third Restatement returned to a negligence basis of liability for design defect cases. ${ }^{187}$ Should the plaintiff be confronted with the onerous burden of proving fault-negligence - by the defendant in the choice of the product's design? Or should the plaintiff be able to succeed on a no fault basis-strict liability imposed if plaintiff merely proves that the product was defectively designed and that plaintiff was injured by the product? Does the language of the Second Restatement, which requires that the defective condition of the product be "unreasonably dangerous," retain a negligence character for the supposedly strict liability cause of action? ${ }^{188}$ Does the language of the Third Restatement, which requires

184. SCHWARTZ ET AL., supra note 54, at 739.

185. RestATEMENT (THIRD) OF TORTS: PRODS. LiAB. § 2 (1998).

186. Id. cmt. d.

187. In referring to design defect cases, the Third Restatement reporters declare: "The policy reasons that support use of a reasonable-person perspective in connection with the general negligence standard also support its use in the products liability context.” Id.

188. In Cronin v. J.B.E. Olson Corp., 501 P.2d 1153, 1162 (Cal. 1972), the California Supreme Court criticized the use of the term "unreasonably dangerous" in the section 402A definition of a defective product, asserting that the language fails to purge the phrase "defective condition" of its negligence complexion. "We think that a requirement that a plaintiff also prove that the defect made the product 'unreasonably dangerous' places upon him a significantly increased burden and represents a step backward in the area pioneered by this court." Id. The court noted that "the very purpose of our pioneering efforts in this field was to relieve the plaintiff from problems of proof inherent in pursuing negligence .... and thereby "to insure that the costs of injuries resulting from defective products are borne by the manufacturers."” Id. (quoting Greenman v. Yuba Power Prods., Inc., 377 P.2d 897, 901 (Cal. 1963)). 
the plaintiff to prove that the product could have been made safer "by the adoption of a reasonable alternative design" and that "the omission of the alternative design renders the product not reasonably safe," really impose a new and more difficult burden on the plaintiff than the burden imposed under the Second Restatement?

I note that although the Third Restatement reestablishes negligence as the basis of liability for design defect cases, there is language in the comments to the section that assists the plaintiff in proving defect. For example, comment d does not preclude a finding of defect even if the dangers of the product were open and obvious, provided the plaintiff is able to establish "that a reasonable alternative design should have been adopted that would have reduced or prevented injury to the plaintiff.","189 Also, although comment $d$ requires the plaintiff to prove a reasonable alternative design "even though the plaintiff alleges that the category of product sold by the defendant is so dangerous that it should not have been marketed at all," 190 nevertheless, the Third Restatement reporters acknowledge: "Several courts have suggested that the designs of some products are so manifestly unreasonable, in that they have low social utility and high degree of danger, that liability should attach even absent proof of a reasonable alternative design."191 In discussing those court decisions, the reporters use the example of a toy gun that shoots hard rubber pellets with sufficient velocity to injure children. Toy guns that are unlikely to cause injury-such as guns that shoot ping-pong balls, soft gelatin pellets, or water-are reasonable alternatives to the hard pellet gun. Even if the realism of the hard pellet gun, and thus its capacity to cause injury, is sufficiently important to those who purchase and use such products to reject those alternatives, the court could impose liability without proof of a reasonable alternative design. The hard pellet toy gun is "defective and not reasonably safe because the extremely high degree of danger posed by its use... so substantially outweighs its negligible social utility that no rational, reasonable person, fully aware of the relevant facts, would choose to use, or to allow children to use, the product., ${ }^{~} 192$ If the capacity to cause injury can be characterized as an

189. Restatement (ThIRD) OF TORTS: PRODS. Liab. $\S 2 \mathrm{cmt} . \mathrm{d}$.

190. Id.

191. Id. cmt. e.

192. Id. 
"egregiously unacceptable quality in a toy for use by children," 193 is the capacity of a .50 caliber rifle to cause injury to a person located a mileand-a-half away from the shooter an equally egregiously unacceptable quality in a rifle-or should I say "toy"-for use by adults?

The two examples also enable the class to consider whether tort lawcivil litigation by injured parties seeking compensation for injuries-is the best way, or even an appropriate way, to resolve problems of this nature. Is legislation, either at the state or federal level, more appropriate? For example, in 2004 and 2005, the House of Representatives considered and voted favorably on a bill entitled the Personal Responsibility in Food Consumption Act—also known as the Cheeseburger Bill—but the Senate did not act on the bill. ${ }^{194}$ The purpose of the bill was to immunize producers and retailers of foods from lawsuits brought by obese customers. $^{195}$ The bill was reintroduced in 2009 with a new title, the Commonsense Consumption Act of 2009. ${ }^{196}$ In contrast, in 2005, Congress passed, and the President signed, the Protection of Lawful Commerce in Arms Act, prohibiting tort actions against manufacturers, distributors, dealers, and importers of firearms or ammunition for harm caused by the criminal or unlawful misuse of firearms or ammunition. ${ }^{197}$ The bill was described as the number one legislative priority of the National Rifle Association (NRA). ${ }^{198}$ Apparently, the NRA is a stronger and more effective lobbyist than fast food industry lobbyists.

\section{CONCLUSION}

I used to get mad at my school, the teachers who taught me weren't cool. You're holding me down, turning me 'round, filling me up with your rules. ${ }^{199}$

193. Id.

194. Personal Responsibility in Food Consumption Act, H.R. 339, 108th Cong. (2004); Personal Responsibility in Food Consumption Act, H.R. 554, 109th Cong. (2005).

195. See Library of Congress, Personal Responsibility in Food Consumption Act, http://thomas.loc.gov/cgi-bin/bdquery/z?d109:HR00554:@@@\&summ2=m\& (last visited Apr. 5, 2010).

196. Commonsense Consumption Act of 2009, H.R. 812, 111th Cong. (2009).

197. Protection of Lawful Commerce in Arms Act, 15 U.S.C. §§ 7901-7903 (2006).

198. Sheryl Gay Stobberg, Congress Passes New Legal Shield for Gun Industry, N.Y. TIMES, Oct. 21, 2005, at A1, available at http://www.nytimes.com/2005/10/21/politics/ 21guns.html?_r=2.

199. The Beatles, Getting Better, on Sgt. Pepper's Lonely Hearts Club Band (Capitol Records 2009) (1967). 
Through the case method and Socratic dialogue, first-year law students learn to develop critical legal analytical skills - to "think like lawyers." Those skills are primarily, if not entirely, intellectual. Although the development of analytical skills is crucial to our students' legal education, it should not exclude all other objectives of our teaching. If that is all law professors do, then we are not being cool. We are doing little more than filling up our students' minds with our rules. Because emotion impacts thinking and learning, we need to adapt our teaching to include an emotional component. We should not fear emotion, banishing it from the classroom. Appropriately used, the "emotion" component of our instruction will not jeopardize the development of analytical skills; it will supplement, but not supplant, that development.

In this Article, I have urged professors teaching first-year law courses to use examples in their classes that generate an emotional response by students. To encourage them to do so, I have provided examples that I have used in my Torts class. When students experience emotion in the classroom, the issue under discussion is internalized. Students are more invested in the discourse. But stimulation of student interest in class discussion is only one benefit. For many students, the use of emotional examples is a reminder of the idealistic goals they had when they chose to attend law school and to become lawyers. In a Torts course, for example, when students experience anger or disgust at a person who has wrongfully hurt another, or when students experience sympathy for the victim of wrongdoing, they also consider the role of attorneys in representing clients in trying to right the wrong-in trying to achieve justice for their client. They believe that, as lawyers, they will be able to use the law to help others and to improve society. Their idealism is renewed. They are receptive to learning the skills necessary for them to become lawyers and to practice law as competent and ethical attorneys. What more can we hope to achieve as teachers? 
